\title{
PRICE MOVEMENT AND UNSTATED OBJECTIONS TO THE DEFECTIVE PERFORMANCE OF SALES CONTRACTS
}

\author{
LAWRENCE R. ENO $\dagger$
}

I

INTRODUCTION

THERE exists in the law of Sales a line of confused cases that may 1 roughly be classified as dealing with "waiver" of unstated objections to the defective performance of a Sales contract. These cases were fostered by the unnecessarily extended interpretation given by the case of Littlejohn v. Shaw to its actual ruling. ${ }^{1}$ In that case, a contract executed March, 1893, for 25 tons of No. 1 cube gambier to be shipped at Singapore for New York contained a provision that the goods were to be of usual good merchantable quality and condition. On the arrival of the goods in New York, the sellers sent a delivery order to the buyers, who returned it, assigning as reasons for their rejection that the goods were not in good merchantable condition and not of good quality. When sued by the sellers for the price and expenses of storage less proceeds on resale, the buyers contended that the sellers had to prove that they had carried out the terms of the contract regarding manner and time of shipment as well as those regarding the condition and quality of the goods, and that since the sellers had not done so, their action should be dismissed. But this argument did not prevail. In affirming a judgment below for the sellers the New York Court of Appeals declared: "In this case, the defendants placed their rejection of the gambier upon two specific grounds, viz: that it was not of good merchantable quality, and that it was not in good merchantable condition. By thus formally stating their objections, they must be held to have waived all other objections. The principle is plain and needs no argument in support of it that, if a particular objection is taken to the performance and the party is silent as to all others, they are deemed to be waived," especially where the deliberateness of the objection shows there has been a consideration of the matter of acceptance and the result reached on particular grounds. Furthermore, the buyers' exception to the denial of their motion to dismiss was waived by them, said the court, thus indicating that the broad rule which it had just set forth was not necessary to a decision of the case. $^{2}$

†Columbia University School of Law. The author wishes to acknowledge his debt of gratitude to Prof. K. N. Llewellyn of the Columbia Law School, without whose as. sistance this article would have been impossible.

1. Llewellyn, Cases and Materials on Sales (1930) 300.

2. Littlejohn v. Shaw, 159 N. Y. 188, 191, 53 N. E. 810, 811 (1899). 
Removal of the buyer's legitimate defenses in this fashion would appear to be justifiable only when there is present some peculiar element in the factual situation, such as the possibility of obviating the complained of defect in performance had timely notice thereof been given, or when there exists cause for the belief that the buyer is endeavoring to squirm out of a contract which he finds suddenly oppressive because of an adverse price movement. Nevertheless, the broad, formal rule enunciated in Littlejolzn v. Shaw has been, and often still is, applied blindly to cases in which neither of these justifying elements is to be found. The explanation of this is no doubt to be found in the belief of most courts that respect for precedent compels such a result. But if it can be shown that the vast majority of the cases out of which this precedent has been solidified contained factual elements which logically and equitably distinguished them from the cases to which the broad rule is to-day sought to be applied, their force as precedent is substantially destroyed. It is the purpose of this article to demonstrate that this is indeed the fact with respect to the rule against the setting up of unstated objections. The most important distinguishing factor to be taken into account is that pointed out by Llewellyn, namely, a falling market between the closing of the deal and the tendered delivery. As a matter of logic and equity, the presence of this factor alone should be sufficient to account for judicial refusal to allow the buyer to set up at trial new objections to the seller's performance. ${ }^{3}$ Accordingly, the cases in which it is found should not at all be regarded as authority for the rigid rule which would bar unstated objections in all circumstances.

II

\section{The State of the Law To-day}

The facts in cases dealing with the subject of unstated objections may vary along many significant lines. The buyer may have been aware of the unstated objections at the time he rejected, or he may not have been; and if he was not, perhaps he should have been. His seller, too, may have been aware of all the objections that the buyer later seeks to set up, or he may not have been. The seller, in fact, may have asked for more definite information, looking to cure. Then there are the cases where the defect could have been remedied had it been made known to the seller at the time of rejection, and there are the cases where it could not have been so remedied, either because time for performance had elapsed, or for some other reason. The buyer who has rejected may seek to set up his later objections only after litigation has commenced, or he may have made them known to the seller at some time after the

3. LLEWELIYN, op. cit. supra note 1 , at 302 . 
original rejection, but before the legal machinery has begun to operate. The stated objections may have been given by means of a carefully planned formal list, or they may have been hastily communicated with the intention of impressing the seller with the fact of rejection rather than the reasons for it. The buyer may have given no reason for rejection at the time of protestation, or may have stated it generally and later sought to set up his specific defenses at the trial. The seller may have been led, in reliance on the stated objections, to act or refrain from acting in some way, or the buyer may have gained some advantage by keeping silent about the defect in performance that he later seeks to set up. Finally, there are the cases that combine various of these different elements. Since any of these numerous fact variations may influence the court, it is important, in order to reach a helpful comparison of results, to analyse each of the fact situations carefully.

In those cases where the buyer does not know of his unstated objections at the time of rejection, the courts generally allow him to set them up for the first time as defenses to a suit by the seller, ${ }^{4}$ except perhaps where his stated grounds give reason to believe that the actual defects were not, so far as concerns normal conditions, really material to him."

By far the majority of the cases, however, deal with the situation where the buyer is held to have known of the unstated defects at the time he rejected performance; and here, generally, the courts, for one reason or

4. Banco Nacional Ultramarino v. First Nat. Bank of Boston, 289 Fed. 169 (D. Mass. 1923) (refusal to accept and pay under a letter of credit); Ungerer \& Co. v. Louis Maull Cheese \& Fish Co., 155 Mo. App. 95, 134 S. W. 56 (1911) (no knowledge of unstated defect till trial and hence Littlejohn $v$. Shaw not applicable; note that the unstated objection was a reasonable approximation of the stated one); Fowler v., Cobb, 232 S. W. 1084 (Mo. App. 1921) (query whether the buyer should not bave known of the unstated defect); Newbery v. Furnival, 56 N. Y. 638 (1874); Granger Co. v. Universal Machinery Corp., 193 App. Div. 234, 183 N. Y. Supp. 711 (2d Dep't, 1920); Prescott \& Co. v. J. B. Powles \& Co., 113 Wash. 177, 193 Pac. 680 (1920) (facts show no knowledge of the unstated defect at time of protestation and attitude is decidedly against Liltlejohn v. Shaw); sco Tuggle v. Green \& Sons, 150 Ga. 361, 370, 104 S. E. 85, 89 (1920); Brown \& Bigelow v. Bard, 64 Misc. 249, 252, 118 N. Y. Supp. 371, 374, (County Ct., 1909); Fielding v. Robertson, 141 Va. 123, 132, 126 S. E. 231, 234 (1925); cf. H. D. Williams Cooperage Co. v. Scofield, 115 Fed. 119 (C. C. A. 8th, 1902) (exempting the $S$ from the waiver rulc).

5. In Armsby Co. v. Raymond Bros.-Clarke Co., 90 Neb. 553, 134 N. W. 174 (1912), there was cancellation before arrival because of poor business conditions and inability to pay. Held, that $B$ cannot object now on the ground of $S$ 's failure to deliver to the carrier per contract. Note that the first refusal was for a reason extrinsic to the contract, which would lead the court to believe that $B$ had no real complaint to make with $S^{\prime}$ s performance, and that this extrinsic reason was a poor market, which would heighten that belief. See Knox v. Schoenthal, 59 Hun 620, 13 N. Y. Supp. 7, 8 (Sup. Ct. 1891), in which the fact that the defect could have been remedied outweighed the fact that it was not actually known. Because $B$ had rejected before $S$ 's performance had reached the stage where $B$ would learn of the defect, the court thought $B$ considered the unstated defect of no importance. 
another, forbid his setting up those objections at the trial. ${ }^{\circ}$ In some of these cases the defects could have been obviated within the contract time had they been made known to the seller. There this is so, the court tends to stress this factor as the one influencing its decision.s But

6. Ginn v. Clark Coal Co., 143 Mich. 84, 106 N. W. 867 (1906) (refusal to complete contract on the ground that the coal sent was not P. G. coal as called for by the contract. Testimony offered to prove the coal rejected was not merchantable. Held, properly escluded. $S$ had a right to rely on the assumption that the rejection beeases it was not P. G. coal was the only ground on which $B$ relied, and it would be unjust to allow him to rely on other grounds at the trial). Motion for rehearing denied. 143 Mich. $\$ 8,107 \mathrm{~N}$. W. 904 (1906) (Should not "P. G. coal" mean "merchantable P. G. coal"?) ; Polson Lo5ging Co. v. Neumeyer, 229 Fed. 705 (C. C. A. 9th, 1916); Banl of Taiwan v. Union Nat. Bank of Philadelphia, 1 F. (2d) 65 (C. C. A. 3d, 1924); Erie Food Products Co. v. Inter-ocean Mercantile Corp., 299 Fed. 71 (C. C. A. 6th, 1924); Hill v. Fruita diercantile Co., 42 Colo. 491, 94 Pac. 354 (1908); Harvard Co. v. Himmelein, 226 Mlich. 691, 193 N. W. 207 (1924) ( $B$ asked to be relieved from contract because customers refused delivery); Gould v. Banks \& Gould, 8 Wend. 562 (N. Y. 1832); Hess v. Kaufherr, 128 App. Div. 526, 112 N. Y. Supp. 832 (1st Dep't, 1908) (stressing deliberatenes of the objections); De Eloff v. Aspegren, 96 Misc. 681, 161 N. Y. Supp. 53 (Sup. Ct. 1916) (B walked out of an arbitration on the stated ground. $B$ precluded from setting up a Statute of Frauds point, though the court intimated that had he rejected generally or kept silent, $B$ would have been protected); Lowinson v. Newman, 201 App. Div. 266, 194 N. Y. Supp. 253 (1st Dep't, 1922); see Keswick v. Rafter, 35 App. Div. 503, 513, 54 N. Y. Supp. 850, 854, (1st Dep't, 1898).

7. There are many interesting questions connected with the topic of obviation of defects which it is not proposed to discuss here in detail, although it is important to note them. There is the primary, and most uncertain problem, of whether the seller has the right to retender after his first tender has been rejected, even though all defects have been made known to him. And if he is allowed to so tender, there is the question of the numbar of times he may be permitted to tender before the buyer changes his position in some way. The very rejection by the buyer might possibly be considered such a change of position as to preclude another tender. There is also the difficult question of just how easy it is to correct the defect. Could it have been so easily remedied that there is no doubt but that it could have been corrected within the time set for performanes, or was it just difficult enough so that possibly, though all defects had been pointed out promptly, the correction would have occurred at a time beyond the contract time for performance? And then there is the question of whether the court should require the seller to show that the defect actually could have been remedied, or assume, from a mere examination of the type of defect, that it could in fact have been obviated. So far as there has actually been a prevention of the correction of a defect by the buyer's failure to set out all objections, there is reason in the rule penalizing such failure.

8. Griffin Grocery Co. v. Richardson, 10 F. (2d) 467 (C. C. A. Sth, 1926); Smith v. Pettee, 70 N. Y. 13 (1877); Knox. v. Schoenthal, 59 Hun 620, 13 N. Y. Supp. 7 (Sup. Ct. 1891); see Miller v. Ungerer, 188 App. Div. 655, 658, 176 N. Y. Supp. 850, 852 (2d Dep’t, 1919) ; Smith Co. v. Moscahlades, 193 App. Div. 126, 134, 183 N. Y. Supp. 500, 507 (1st Dep't, 1920); Strasbourger v. Leerburger, 233 N. Y. 55, 60, 134 N. E. 834, 836 (1922) (advocating the confinement of the Litllejolm v. Shaw doctrine to the "obviation" cases); Hyman v. Hullman, 205 App. Div. 119, 122, 199 N. Y. Supp. 366, 367 (1st Dep't, 1923); Jardella v. Welin Davit \& Boat Corp., 219 App. Div. 353, 360, 220 N. Y. Supp. 115, 121 (2d Dep't, 1927) ; cf. Mente v. De Witt Rice Mill Co., 251 Fed. 252 (C. C. A. 
there is very little investigation to see whether the defect in fact could have been remedied; there being, rather, a "presumption" by the court of the possibility of obviation from a mere examination of the type of defect." The "presumption" is indulged often to give reason to an otherwise unjustifiable decision, though cases in such jurisdictions have been similarly decided even without the presence of the factor of obviation. ${ }^{10}$ Some of the cases mention the fact that litigation had already begun before the buyer voiced his objections. ${ }^{11}$ This is apparently con-

8th, 1918) (refusal to perform because the contract in question depended on another that was never made; held, $B$ can defend on the ground the minds never met, since the defect could not have been obviated). And see Western Grocer Co. v. New York Oversea Co, 28 F. (2d) 518,520 (N. D. Cal., 1928) ( $B$ objected to defects in documents promptly on receipt, and since they could not be obviated, the rule that one refusing performance on one ground cannot rely on another that could be remedied did not apply, especially where the defects were concealed during early stages of controversy).

9. E.g. in Knox v. Schoenthal, 59 Hun 620, 13 N. Y. Supp. 7 (Sup. Ct. 1891), in which hops were rejected because "slack dried and damp", there was a question whether tho defect in weight later relied on could in fact have been obviated. Note that, since the contract was for all of $S$ 's hops, all those which he had were presumably delivered; and he was not privileged to make up the deficiency from other sources. Though the defect might have been corrected by rebaling (since the total weight was over the contract minimum) there is a question whether it could have been so corrected within the contract time. Secondly, and more important, note that the court nowhere considered these factual elements. Also see Grifin Grocery Co. v. Richardson, 10 F. (2d) 467 (C. C. A. 8th, 1926), where time must have been deemed to have been of the essence becauso of the fluctuating market. Query: Smith v. Moscahlades, 193 App. Div. 126, 134, 183 N. Y. Supp. 500, 507, (1st Dep't, 1920), especially if time were in question.

10. Compare the New York cases in note 6, supra, with those in note 8, supra.

11. United Fruit Co. v. Bisese, $25 \mathrm{~Pa}$. Super. 170 (1904) (holding that $S$ had a right to know all the grounds of refusal in deciding what action to take, and that such choico had been denied him by the failure of $B$ to object to quantity); cf. Rochevot v. Wolf, 96 App. Div. 506, 89 N. Y. Supp. 142 (4th Dep't, 1904) (suit by $B$; in deciding whether to litigate or not $S$ had a right to rely on the defects specified as the only ones he would have to contend with. Hiscock, J., stressed the deliberateness of the notice sent.)

Polson Logging Co. v. Neumeyer, 229 Fed. 705 (C. C. A. 9th, 1916); Godchaux Sugars Inc. v. Meridian Wholesale Co., 289 Fed. 359 (C. C. A. 5th, 1923); Frank \& Meyer Neckwear Co. v. White, 29 Ga. App. 694, 116 S. E. 855 (1923) (objection that too many tieg were sent maintained even at the trial; granting of subsequent motion by $B$ for nonsuil on ground that too few were sent, reversed); Cobb Lumber Co. v. Sunny South Grain Co., 36 Ga. App. 140, 135 S. E. 759 (1926); see Cadick Milling Co., v. Valdosta Grocery Co., 72 Ind. App. 534, 546, 126 N. E. 240, 244 (1920). But cf. St. John Bros، Co. v. Falkson, 237 Mass. 399, 130 N. E. 51 (1921) (failure to mention wrong delivery prior to litigation not decisive of the waiver of the right to set up such reason as a defense, but was a question for the jury). Note that the goods were never received by $B$. It is reasonablo to suppose that other reasons were given before litigation in this case, but qucry. Innan, Akers \& Inman v. Elk Cotton Mills, 116 Tenn. 141, 92 S. W. 760 (1906) (cancellation which $S$ refused to accept. Held, $S$ refused the repudiation and thereforc kept the contract alive so $B$ could avail himself of all breaches of $S$, and pleading could be amended to include an unstated objection) Note that the original reason fairly covers the new facts and that there was no knowledge by $B$ at time of rejection. 
ceived to be a change of position by the seller induced by the stated objections sufficient to bar the buyer's reliance on other defenses. But there is no investigation to see whether the suit was hurriedly instituted by the seller, perhaps to cut off unstated objections of which the seller then had knowledge. Moreover, the rigid rule of "waiver" apparently operates also in those cases in which the buyer has raised the new objection before litigation has begun, but after a first notice had been sent; for there too courts have held that the second objection came too late and must be deemed to have been "waived" because of failure to include it in the first notice. ${ }^{12}$ Perhaps the principal doctrinal importance of the cases that stress the two facts of possible "obviation" and the commencement of litigation is their tendency to draw an estoppel out of these facts. ${ }^{13}$

Little stress is laid, in these cases, on the formality of the objection. The courts largely argue as though a hurried telegram sent under pressure was the equivalent of a letter sent on the seller's express request, with litigation in prospect, and detailing the contract and the arrival of the goods, and listing the reasons for rejection. ${ }^{14}$ Most of those cases

12. Linger v. Wilson, 73 W. Va. 669, so S. E. 1108 (1914) (second objection, sent on week after first, precluded). Note the apparent stretching of the facts, the court saying that $B$ said in his first letter that he would accept if his objection was remedied. But compare the stated facts; see Mianda v. Etienne, 93 App. Div. 609, 611, 87 N. Y. Supp. 588, 593 (1st Dep't, 1904) (second objection mailed to $S$ in France before, but not received before suit by $B$ was brought). Even though $S$ had been given an opportunity to remedy the defect before suit, query whether he could have retendered at all, and if $\mathbf{s}$, whether he could have done so within the contract time. Note that though notice of objection apparently arrived before notice of suit, $S$ did nothing to correct this defect. Brown \& Bigelow v. Bard, 64 Aissc. 249, 252, 118 N. Y. Supp. 371, 374, (County Ct., 1909) (defendant would have been limited to the objections in his first letter if he had had complete knowledge of the facts); E. L. Rice \& Co. v. Roberts, 172 S. E. 615,616 (W. Va., 1934) (rejection because of poor business conditions. $S$ refused to secept rejection, and $B$ replied referring to $S$ 's fraud and offering to take if $S$ would stand risl of payment; held, defense of fraud, even if relied on as a reason for rejection and not merely stated in the second letter, would be insufficient because not given in the first.).

13. See, e.g., Godchaux Sugars, Inc., v. Meridian Wholesale Co., 289 Fed. 359 (C. C. A. 5th, 1923); Rand v. IIorse, 289 Fed. 339 (C. C. A. Sth, 1923); Cobb Lumber Co. v. Sunny South Grain Co., 36 Ga. App. 140, 135 S. E. 759 (1926) (the new ground cannot be set up to render injurious to $S$ the action [suit] taken by him on the ground of the defect originally assigned). Note that the original rejection was because of unsatisfactory quality and price, and that there was an offer to take at lower price. Knos v. Schoenthal, 59 Hun 620, 13 N. Y. Supp. 7 (Sup. Ct. 1891); Rochevot v. Wolf, 96 App. Div. 506, S9 N. Y. Supp. 142 (4th Dep't, 1904); United Fruit Co. v. Bisee, 25 Pa. Supar. 170 (1904).

14. No case permitting the buyer to set up the unstated defects at the trial has been found which rests in any way on the possible fact that the notice of rejection was bastily sent in order to acquaint the seller with the state of affairs so that he might best know how to proceed. But in such a case there is much to be said against penalizing an honest buyer who hastily communicated his rejection, perhaps in order that the seller might not 
that do mention the deliberateness of the statement of objections do so merely to add a make-weight argument, and do not pivot their arguments about this point. ${ }^{15}$ But much stress should be laid upon this factor. For even conceding that pressure brings out the real reasons for a business man's rejection, it must be admitted that a hurried wire will omit many things considered essential, in the belief that what has been stated is sufficient. ${ }^{18}$ A detailed letter, evidencing thought and consideration, may more nearly point to a reliance on only the facts stated.

In those cases where the buyer was not aware of the unstated defects, but should have been, the courts generally treat him as if he had known them. ${ }^{17}$ Only a few cases stress the point that there was no actual

lose any possible sales, and acting solely for the benefit of the seller. As was said in Johannes Bros. Co. v. Czarnikow-Rionda Co., 121 Misc. 474, 481, 201 N. Y. Supp. 409, 415 (Sup. Ct. 1923) "ordinarily a business man, discovering defects in goods supplied by a reputable dealer, does not assume that he will be obliged to resort to legal proceedings to protect his rights, nor does he consult his lawyer as to the form of letter he will write, but merely sends the dealer a complaint ..." The consultation with a lawyer is usually resorted to only when there is a fear of legal action by the other party, or a desire for legal action by the complainant. A business man's honesty may woll be gauged by his hesitancy to resort to legal action, and the actions and statements of a business man should have their effect in this field judged from his point of view and not from the lawyer's. See also as to the treatment of a business man's actions, United Engine Co. v. Junis, 196 Iowa 914, 195 N. W. 606 (1923); Nathan Isaacs, The Inditstrial Purchaser and the Sales Act (1934) 34 Cox. L. Rev. 262.

15. Bank of Taiwan v. Union Nat. Bank of Philadelphia, 1 F. (2d) 65 (C. C. A. 3d, 1924); De Hoff v. Aspegren, 96 Misc. 681, 161 N. Y. Supp. 53 (Sup. Ct. 1916); Carson Petroleum Co. v. Balboa Trading Co., 120 Misc. 389, 198 N. X. Supp. 556 (Sup. Ct. 1923); E. L. Rice \& Co. v. Roberts, 172 S. E. 615 (W. Va., 1934). The cases which apparently place most stress on this factor are Littlejohn v. Shaw, $159 \mathrm{~N} . \mathrm{Y} .188,53 \mathrm{~N}$. E. 810 (1899); Rochevot v. Wolf, 96 App. Div. 506, 89 N. Y. Supp. 142 (4th Dep't 1904); Brown \& Bigelow v. Bard, 64 Misc. 249, 118 N. X. Supp. 371 (County Court, 1909); Granger Co. v. Universal Machinery Corp., 193 App. Div. 234, 183 N. Y. Supp. 711 (2d Dep't, 1920).

16. LLewELLYN, op. cit. supra note 1 , at 302 .

17. Oakland Sugar Mill Co. v. Wolf Co., 118 Fed. 239 (C. C. A. 6th, 1902) (defects, though not known before suit, were not latent, could have been discovered by diligent inspection, and therefore cannot be urged as a defense); Germain Fruit Co. v. Roberts \& Co., 8 Pa. Super. 500 (1898) (defense of late shipment, date of shipment not being known before trial due to $S$ 's negligence. Held, late arrival should have resulted in inquiry into time of shipment, and then $B$ could have protested on that ground. Having protested and induced an arbitration on another ground, defense of time must be considered waived.); see Tuggle v. Green \& Sons, 150 Ga. 361, 370, 104 S. E. 85, 89 (1920); Miller v. Ungerer \& Co., 188 App. Div. 655, 658, 176 N. Y. Supp. 850, 852 (2d Dep't, 1919) (defendant should have known at the time that receipt was non-negotiable). But see O'Donobue v. Leggett, 55 Hun 607, 8 N. Y. Supp. 426, 430 (Sup. Ct. 1889) (tags indicating deficiency were not seen by $B$ apparently because of his own negligence and were therefore not known to him until trial. Held, objection to deficiency not precluded.) But sce concurring opinion of Davis, P. J., id. at 431 . Aff'd O'Donohue v. Leggett, 134 N. Y. 40, 31 N. E. 269 (1892), where the deficiency was not considered material. 
knowledge at the time of protestation, and these fer then proceed as though there were. The others do not even bother to mention the fact that there was no actual knowledge. A court would seem to be justified in so proceeding.

But where the seller has knowledge of the unstated defects, he should be prepared to litigate them regardless of whether the buyer has stated them originally; for there seems little to ground an estoppel as to such defenses. It might be said that the seller has been led to litigate in the belief that only the defects stated would be relied on at the trial. But there being no reasonable basis for him so to presume, ${ }^{16}$ this argument seems to be but an assumption of the conclusion. For the court to make such a presumption for him seems unjustified. In such matters as defects in shipment, late performance, and general defenses to a suit, such as "meeting of the minds," the seller may safely be presumed to have as much knowledge as the buyer. Although there is very little mention in the cases themselves of such knowledge of the seller, there appears to be some tendency to allow the buyer to set up as defenses to the seller's suit defects in performance of which the seller is presumed to have cognizance. ${ }^{19}$ Certainly is this true of general defenses to the suit,

1S. Save so far as the effect of normal commercial leeway is felt. As to this, Llewellyn, What Price Contract?-An Essay in Perspective (1931) 40 YaLE L. J. 704, expecially at 722. Llewellyn points out that while the law seeks infexible measures of performance, non-legal obligation is flexible within a "range of permissible variation," which, before narrowing by either party pending performance, is wider, and even after narroming, may still be wider than the range commonly recognized at law; and that the law is arbitrary in so far as it does not act in the light of these practices, Commercial leeway is extremely difficult to demonstrate in any single case. It is based on a series of dealings in the given industry or between the given individuals in the course of which the defect in question has appeared but the performance was accepted nevertheles. Unless this is shown, it is hazardous to assume commercial leeway in any case as to the particular defect, except in so far as the buyer expressly states that be would have received the goods, despite the defect, in normal times. See in this connection Peterson Bros. v. Mfincral King Fruit Co., 140 Cal. 624, 74 Pac. 162 (1903), in which plaintiff testified that had the market not gone down he would have accepted, because he could put stuff through on a rising market that he could not on a falling.

19. In this connection compare the following two lines of cases. Mrengel \& Bros. Co. v. Handy Chocolate Co., 10 F. (2d) 293 (C. C. A. 1st, 1926) (late tender not preduded); Western Grocer Co. v. New York Oversea Co., 2S F. (2d) 518 (N. D. Cal. 1928) (defects in drafts known to $S$ ) ; Tascott v. Rosenthal, $10 \mathrm{IIL}$ App. 639 (18S2) (shipment ahead of time not "waived" because not stated); St. John Bros. Co. v. Fallsson, 237 Mrass. 399, 130 N.- E. 51 (1921) (delivery to wrong carrier not precluded); Woldert Grocery Co. v. Pillman, 191 Mo. App. 15, 176 S. W. 457 (1915) (delivery at wrong place); Fowler v. Cobb, 232 S. W. 1084 (Mo. App., 1921) (defect in quality known to the seller); Sabin Robbins Paper Co. v. Cal Hirsch \& Sons Mercantile Co., 263 S. W. 479 (Mío. App., 1924) (late shipment); O'Donohue v. Leggett, 55 Hun 607, 8 N. Y. Supp. 426 (Sup. Ct. 1859) (deficiency in quantity apparently known to the seller, or should have bzen knowntags on bags); Brown \& Bigelow v. Bard, 64 Mrisc. 249, 118 N. Y. Supp. 371 (County 
which, both because of the presumptive knowledge of the seller and the impossibility of obviation, should under no theory be considered abandoned because of non statement. ${ }^{20}$

With respect to all these fact situations, those courts that do theorize reason on the basis of estoppel $1^{21}$ or something that they call "waiver." The application of one theory does not necessarily exclude the other in the same jurisdiction; and in the same case a court will often mention both as good law, while applying one. ${ }^{22}$ Estoppel, indeed, has been thought to be the reason for the rule. ${ }^{23}$ It is, however, doubtful whether the facts in most of the cases show any actual basis for the application of that doctrine. ${ }^{2 t}$ "Estoppel" here usually appears to be

Ct. 1909) (defect in quantity known to the seller held not precluded); Petersburg Flro Brick \& Tile Co. v. American Clay Machinery Co., 89 Ohio St. 365, 106 N. E. 33 (1914) (defect in manner of shipment not precluded). But compare the following: Higging v. California Prune \& Apricot Growers, 16 F. (2d) 190 (C. C. A. 2d, 1926) (method of delivery; but note that original rejection was as to price); Cobb Lumber Co. v. Sunny South Grain Co., 36 Ga. App. 140, 135 S. E. 759 (1926) (time of shipment; but noto that the reason given was that the price was too high); Armsby Co. v. Raymond Bros.* Clarke Co., 90 Neb. 553, 134 N. W. 174 (1912) (improper delivery; but note that the reason given for rejection was the poor market); Keswick v. Rafter, 35 App. Div. 508, 54 N. Y. Supp. 850 (1st Dep't, 1898) (shipment by different route) ; Hess v. Kaufherr, 128 App. Div. 526, 112 N. Y. Supp. 832 (1st Dep't, 1908) (late shipment); Germain Fruit Co. v. Roberts \& Co., 8 Pa. Super. 500 (1898) (same); United Fruit Co. v. Bisese, $25 \mathrm{~Pa}$. Super. Ct. 170 (1904) (excess quantity known to the seller). As to defects in shipment, watch for such things as negligent shipping clerk.

20. Mente v. De Witt Rice Mill Co., 251 Fed. 252 (C. C. A. 8th, 1918) ("meeting of the minds"); Interstate Iron \& Steel Co. v. Northwestern Bridge \& Iron Co., 278 Fed. 50 (C. C. A. 7th, 1922) (invalidity of the contract); Union Brokerage Co. v. Beall Bros,, 30 Ga. App. 748, 119 S. E. 533 (1923) (failure of consideration); Bates v. Cashman, 230 Mass. 167, 119 N. E. 663 (1918) (false representations; a stock case); see Savannah Chemical Co. v. W. R. Grace \& Co., 293 Fed. 145, 147 (C. C. A 5th, 1923) ("walver" mentioned only as to one defense not stated at the time of repudiation, but not to the one that the contract was unilateral and void, on which point evidence was admitted). But compare a recent case holding a general defense precluded. Siegel v. Waynesboro Knitting Co., 7 F. Supp. 693 (S. D. N. Y. 1934), criticized (1935) 35 Cor. L. REv. 106.

21. See cases note 13, supra; Oakland Sugar Mill Co. v. Wolf Co., 118 Fed. 239 (C. C. A. 6th, 1902), cited note 17, supra; Second Nat. Bank of Allegheny v. Lash Corp., 299 Fed. 371 (C. C. A. 3d, 1924) (stressing "examination of the record" to find an estoppel, then finding none in the facts but presuming one as the natural result of silence, though pointing out that had the defendant given no reason at all, ho could defend on any ground he chose); Germain Fruit Co. v. Roberts \& Co., 8 Pa. Super. Ct. 500 (1898), cited note 17 , supra.

22. See in this connection, Oakland Sugar Mill Co. v. Wolf Co., 118 Fed. 239 (C. C. A. 6th, 1902); Granger Co. v. Universal Machinery Corp., 193 App. Div. 234, 183 N. Y. Supp. 711 (2d Dep't, 1920); List \& Son Co. v. Chase, 80 Ohio St. 42, 88 N. E. 120 (1909); Fielding v. Robertson, 141 Va. 123, 126 S. E. 231 (1925).

23. 2 WILliston, SALES (2d ed. 1924) \$\$ 494a, 495.

24. Few of the cases cited in note 21 , supra, point out any action that the plaintiff has taken in reliance on the fact that only the stated objections would be relied on by tho 
the label for a result that the court wishes to reach rather than a justifiable inference from the facts. And in most instances, even if all the necessary elements for an estoppel were present, including action in reliance to the actor's damage, it is doubtful whether such reliance on the part of the seller would be reasonable. An assumption on the part of the seller that the buyer is going to rely solely on the defects he has mentioned seems unwarranted, both because it is not grounded in fact ${ }^{25}$ and because - under existing (though unfortunate) law-the buyer is

defendant in defending the lawsuit. Those that do, Rochevot v. Wolf, 96 App. Div. 505, 89 N. Y. Supp. 142 (4th Dep't, 1904), and United Fruit Co. v. Bizese, $25 \mathrm{~Pa}$. Supor. 170 (1904), both cited in note 13, supra, fail to show in what way the plaintiff has been damaged by that action. In those cases that stress the fact of litigation, why irdecd should a plaintiff recover who would not have litigated had he known all the facts? Why should he not be under a duty to inquire as to all the defenses that the defendant might have before suing? Why should he not be under a duty to perform strictly according to the contract, except in so far as the factor of commercial leeway is involved? Should the buyer be penalized because of the mistake of the seller who perhaps is "trying to put one over on him," suing before the buyer discovers all the defects? And if it be thought the seller has been misled into litigation because of the unstated defects when he would not otherwise have brought suit, wherein would he be damaged if the action were dismissed and its costs imposed on the buyer? Some cases whose facts do show action on the part of the seller induced by the stated objections do not procesd on the theory of estoppel. Drucklieb v. Universal Tobacco Co., 106 App. Div. 470, 94 N. Y. Supp. 777 (1st Dep't, 1905) (reduction of price); De Hoff v. Aspegren, 96 Jilice 6S1, 161 N. Y. Supp. 53 (Sup. Ct. 1916) (arbitration; proceeding on the theory of waiver). But cf. Germain Fruit Co. v. Roberts \& Co., \& Pa. Super 500 (1898) (arbitration mentioned and estoppel theory used).

None of the cases specifically point out any action that the phintiff has refrained from, owing to the defendant's conduct. As to the obviation of defects, all the factors that should first be considered, and which are not considered, even before we inquire whether the seller would have acted but for the buyer's statement, are set forth in note 7 , stpgra. Nor do the cases set forth clearly that the buyer's reasons were a but-for cause of the seller's inaction. Where the buyer's reasons did actually operate as such a but-for causa. there is meaning in the rule. See in this connection Knox v. Schoenthal, 59 Hun 620, 13 N. Y. Supp. 7 (Sup. Ct. 1891); Second Nat. Bank of Allegheny v. Lash Corp., 299 Fed. 371 (C. C. A. 3d, 1924).

25. Several exceptions must be made to this statement. One is where the factor of commercial leeway is involved; where the buyer would have accepted in spite of the defect, had times been normal. Another exception is the line of cases in which the buyer has said in effect to the seller, "If you remedy this defect, I will accept." Here such an assumption may be warranted. See in this connection Peterson Bros. v. Mineral Fing Fruit Co., 140 Cal. 624, 74 Pac. 162 (1903); Linger v. Wilson, 73 W. Va. 669, 80 S. E. 1108 (1914), cited in note 12, supra, (assuming the court's interpretation of the facts). Another possible exception might be where the buyer offers a lower price to the seller, for the lower price might often be considered a remedy of the defect stated, and therefore substantially like the first situation - often, not always, e.g., where a drop in the market or a lack of funds is mentioned. See in this connection Cobb Lumber Co. v. Sunny South Grain Co., 36 Ga. App. 140, 135 S. E. 759 (1926) (offer of a lower priø); Olces: v. Mobile Fruit \& Trading Co., 112 Ml. App. 281 (1904) (same). 
under no duty at all to disclose the defects in the seller's performance. ${ }^{20}$ To penalize an honest buyer who speaks, however hastily, seems doubly unfair when a rogue who sits silent can defend a seller's action on any ground that he sees fit. The estoppel theory is most satisfactorily used as a means of getting away from the rigid rule, the court in such instances declaring that the reason of the rule against the setting up of unstated objections is estoppel, and that the facts of the particular case do not show an estoppel, which is most often true. ${ }^{27}$

What has been said of estoppel is equally true of "waiver." Certainly "waiver" in this situation labels no distinct legal principle, and certainly not what is ordinarily meant by that term. Waiver ordinarily connotes the "intentional relinquishment of a known right"28 without the necessity for consideration. It can rarely be said with reason that a person has intentionally abandoned a possible defense that he might have to a lawsuit. ${ }^{29}$ The term "waiver" is evidently the term by which the courts justify loosely a conclusive presumption that all other defenses are abandoned when the buyer states only some.

Courts dissatisfied with the rigid rule as followed in most of the cases have found several means of getting away from it. There are first the

26. Nelson v. Imperial Trading Co., 69 Wash. 442, 125 Pac. 777 (1912); seo Second Nat. Bank of Allegheny v. Lash Corp., 299 Fed. 371,373 (C. C. A. 3d, 1924) ; 2 WILLSTON, Contracts (1920) $\S 744 ; 2$ Wriciston, Sales, (2d ed. 1924) $\S 495$. But note that the author is not supporting the "no duty to disclose" rule. The reasoning is from one poor (but existing) rule to another. The logical conclusion is to change both. Cf. Car. Crv. Code, (Deering, 1931) § 1501 and Car. Code Crv. Proc. (Deering, 1931) § 2076.

27. Mente v. De Witt Rice Mill Co., 251 Fed. 252 (C. C. A. 8th, 1918); Mengel \& Bro. Co. v. Handy Chocolate Co., 10 F. (2d) 293 (C. C. A. 1st, 1926); Carter-Moss Lumber Co. v. Lomax, 30 Ga. 718, 119 S. E. 534 (1923); Drew v. Breedlove, 30 Ga. App. 722, 119 S. E. 532 (1923); Union Brokerage Co. v. Beall Bros., 30 Ga. App. 748, 119 S. E. 533 (1923); Tufts v. McClure Bros., 40 Iowa 317 (1875); Bates v. Cashman, 230 Mass. 167, 119 N. E. 663 (1918) (sale of stock case and court considered defendant had expressly reserved different grounds in his letter of protestation); Noble v. Pirson, 204 Mich، 306, 169 N. W. 860 (1918) ; List \& Son Co. v. Chase, 80 Ohio St. 42, 88 N. E. 120 (1909) (held, $B$ could wait till arrival to object to defects, though known to him before, since the defect could not have been remedied at either time, the rule as to waiver of unstated objectlong operating only where there is estoppel or a real waiver); Petersburg Fire Brick \& Tile Co. v. American Clay Machinery Co., 89 Ohio St. 365, 106 N. E. 33 (1914); sce Tascott v. Rosenthal, 10 IIl. App. 639, 642 (1882); Lefferts v. Weld, 167 Mass. 531, 536, 46 N. E. 107, 108 (1897) (intimation that had the plaintiff relied on the omission to his damage, result would have been contra); Price v. Engelke, 68 N. J. L. 567, 570, 53 Atl. 698, 699 (1902); Jardella v. Welin Davit \& Boat Corp., 219 App. Div. 353, 360, 220 N. X. Supp. 115, 121 (2d Dep't, 1927).

28. See Mengel \& Bro. Co. v. Handy Chocolate Co., 10 F. (2d) 293, 296 (C. C. A. 1st, 1926).

29. In the situations presented in note 25 , supra, an abandonment of a defense might be worked out: the reduction in price or the remedying of the defect compensating for the loss; and commercial leeway, acquiesced in, being good reason for barring purely legalistic objection. 
courts that openly repudiate that mechanically applied doctrine. ${ }^{80}$ These are the brave few that have cropped up every now and then. There are those that hold that the buyer may set up such defenses as he chooses where he has rejected generally; ${ }^{31}$ those that hold that an insistence by the seller that the buyer perform after he repudiates indicates non-acquiescence in the repudiation, keeping the contract alive so that other defenses may be brought in; ${ }^{32}$ those that consider the defect in performance a breach that could not be eradicated or changed by anything that the buyer said or did;33 those that leave the question of waiver to the jury as a question of fact; ${ }^{34}$ and at least one that says by way of dicta that it does not apply except where there is an enforceable contract. ${ }^{35}$ All

30. Woldert Grocery Co. v. Pillman, 191 Mio. App. 15, 176 S. W. 457 (1915 (acsignation of one reason does not do away with the necessity on the part of $S$ of showing full performance to recover, citing Ungerer \& Co. v. Louis Miaull Cheese \& Fith Co., 155 Mo. App. 95, 134 S. W. 56 (1911), cited note 4, sutpra); Sabin Robbins Paper Co. v. Cal Hirsch \& Sons Mercantile Co., 263 S. W. 479 (Mo. App. 1924); Price v. Engelke, 63 N. J. L. 567, 53 Atl. 698 (1902) (unless $S$ made such delivery as was performance on his part, $B$ could reject, the reasons operating in his mind for rejecting being of no moment, there being nothing to show they were communicated to $S$ or that $S$ was in any ray misled); - Perry v. Mt. Hope Iron Co., 16 R. I. 318, 15 Atl. 87 (1888); Prescott \& Co. v. J. B. Powles \& Co., 113 Wash. 177, 193 Pac. 680 (1920), cited note 4, stgra. The emphasis of this case on the suit for the purchase price and its citation of Inman, Akers \& Inman v. Elk Cotton Miils, 116 Tenn. 141, 92 S. W. 760 (1906), stressing the point that the plaintiff had not acquiesced in the buyer's repudiation of the contract, may be considered as showing a tendency to hold that a suit for the price indicates the nonacquiesence of the seller in the buyer's repudiation, so that the buyer may bring in other defenses. Sa Williams Cooperage Co. v. Scofield, 115 Fed. 119, 121 (C. C. A. 8th, 1902); Strasbourger v. Leerburger, 233 N. Y. 55, 60, 134 N. E. 834, 836 (1922).

31. Noble v. Pirson, 204 Mich. 305, 169 N. W. $\$ 60$ (1918) (a letter saying that if the stock had been as guaranteed $B$ would have made money but now would lose, following a telegram that customers would not accept and a letter enumerating defects, beld to be a claim they did not comply with the contract, which $B$ could prove); Jardells v. Welin Davit \& Boat Corp., 219 App. Div. 353, 220 N. Y. Supp. 115 (2d Dep't, 1927) (rejection for specified defects and because the boat showed careles construction and poor workmanship held to be, in the circumstances, broad enough to cover every defect proved by $B$ in suit to recover the price, the $S$, moreover, not objecting to proof of the defects on the ground of surprise).

32. Richard v. Haebler, 36 App. Div. 94, 55 N. Y. Supp. 583 (1st Dep't, 1899); International Cheese Co. v. Garra, 107 Misc. 344, 176 N. Y. Supp. 523 (Sup. Ct. 1919); Inman, Akers \& Inman v. Elk Cotton Mrills, 116 Tenn. 141, 92 S. W. 760 (1906).

33. Tascott v. Rosenthal, 10 Ill. App. 639 (1882); cf. Aetna Esplosives Co. v. Diamond Alkali Co., 277 Pa. 392, 121 Atl. 201 (1923) ( $S$ not precluded from objecting to the past delay in giving a required monthly notice, though it did not so complain in its letter of cancellation, since as to the past month the contract was not cancelled, but executed, and the rights of the parties thereunder had been fixed).

34. Tufts v. McClure Bros., 40 Iowa 317 (1875); St. John Bros. Co. v. Fallsson, 237 Mass. 399, 130 N. E. 51 (1921), cited note 11, supra; cf. Cavley v. Weiner, 236 N. Y. 357, 140 N. E. 724 (1923) (not a sale of goods case).

35. See Keiser \& Son Co. v. Hallock, 201 App. Div. 186, 188, 190, 194 N. Y. Supp. 
these cases indicate that dissatisfaction with the rigid rule is causing the courts to work toward its modification. ${ }^{\mathbf{3 6}}$

III

\section{Historical Development}

As Professor Williston has pointed out, the doctrine that refusing performance for one reason precludes setting up other reasons is not peculiar to the law of Sales. ${ }^{37}$ It has been applied in the fields of Vendor and Purchaser, ${ }^{38}$ Insurance, ${ }^{38}$ Factors and Brokers, ${ }^{40}$ and cases where a tender of money is made and refused on one ground or another. ${ }^{41}$ Many of the cases which have invoked the doctrine in fields where it is more or less justifiable have been used as precedents by the courts which

737, 739, 741 (3d Dep't, 1922), in which Kellogg, J., concurring says that the rule of Littlejoln $v$. Shaw does not prevent reliance upon the Statute of Frauds as a defense at trial, although the rejection has been made upon other grounds.

36. Only one state, California, has seen fit to legislate on this subject. The pertinent section of the Civil Code is Section 1501 (Deering, 1931), and of the Code of Civil Procedure is Section 2076 (Deering, 1931):

§ 1501: "All objections to the mode of an offer of performance, which the creditor has an opportunity to state at the time to the person making the offer, and which could be then obviated by him, are waived by the creditor, if not then stated."

$\S 2076$ : "The person to whom a tender is made must, at the time, specify any objection he may have to the money, instrument, or property, or he must be deemed to have waived it; and if the objection be to the amount of money, the terms of the instrument, or the amount or kind of property, he must specify the amount, terms or kind which he requires, or be precluded from objecting afterwards."

The "which could be obviated" clause of Section 1501 has been held to be a qualification of Section 2076. Young v. Rocha, 65 Cal. App. 15, 222 Pac. 861 (1923).

Even before the statute was passed, there was no strong case in California applying the rigid rule which this reviewer has found. Peterson Bros. v. Mineral King Fruit Co., 140 Cal. 624, 74 Pac. 162 (1903), appears to be an express waiver case. After the statute there appears to have been a closer scrutiny on the part of the courts in order to see whether the defects actually could have been obviated or not, apparently the result of having the fact impressed upon them by the statute. Young v. Rocha, stupra; Ward-Lewis Lumber Co. v. Mahoney, 70 Cal. App. 708, 234 Pac. 417 (1925) (confining the statute to the mode of performance, and tending to arrive at a still more liberal rule).

It is perhaps fortunate that a poorly conceived Iowa statute has never been extended to a Sales case on this point, for it embodies the rigid waiver rule. Iows Code (1931) $\S 9450$.

37. 2 Williston, Sales (2d ed. 1924) § 494b.

38. Davis \& Rankin Bldg. \& Mfg. Co. v. Dix, 64 Fed. 406 (C. C. W. D. Mo. 1894); Higgins v. Eagleton, 155 N. Y. 466, 50 N. E. 287 (1898); Haney v. Hatfield, 241 Pa. 413, 88 Atl. 680 (1913).

39. Union Fraternal League v. Sweeney, 184 Ind. 378, 111 N. E. 305 (1916); see MCCormick \& Sons v. Royal Insurance Co., 163 Pa. 184, 193, 29 Atl. 747, 750 (1894).

40. Holbrook v. Wight, 24 Wend. 169 (N. Y. 1840); Winter v. Coit, 7 N. Y. 288 (1852).

41. Moynahan v. Moore, 9 Mich. 9 (1860); 3 Wuriston, Contracts (1920) $§ 1819$. 
sought to apply the doctrine to the law of Sales. 2 Such a use of precedents, unless the situations are very similar, is an evil to which the "common law" system is prone. ${ }^{42 a}$ This field is no exception to the rule.

The theory of "waiver" of unstated objections had its inception in England. But it is important to note that it arose in the English "moneytender" cases and before England had Sales cases to which to apply the rule. Wright $v$. Reed, ${ }^{43}$ the earliest decision discovered, was a case in which a tender of bank-notes was held to be a good tender if no objection was made on that score, there being a question at the time whether bank-notes were legal tender. This case was closely followed by that of Lockyer v. Jones, ${ }^{44}$ in which an objection as to the amount of the tender of money was deemed a waiver of any objection to the form of tender, Lord Kenyon saying that had the latter objection been made, the defendant might have taken the money from his pocket and tendered it, thus correcting the defect. Later, ${ }^{45}$ in Polglass v. Oliver, ${ }^{40}$ the court again used the same argument.

When Sales cases finally arose in England in which the doctrine could be employed, the English courts on the whole refused to apply

42. As an example, without intimating that the rule was justifiable in this particular cace, Railway Co. v. McCarthy, 96 U. S. 258 (1S77), might be cited. That was an action for damages for "negligence in the execution of a contract of afireightment," and y'et it bas been cited by many Sales cases as authority for their holdings.

$42^{\mathrm{A}}$. Cf. LIEWELIYN, op. cit. supra, n. 1, at 98 .

43. 3 T. R. 554 (K. B. 1790).

44. Peake 238, note (N. P. 1796).

45. Lockyer v. Jones, Peake, 238 note (N. P. 1796) was followed by Grigby v. Oales, 2 Bos. \& P. 526, 529 (C. P. 1801), which was an action on a promissory note. Chambre, J. said obiter: "It has been thought that the courts went a great way in holding a tender in bank notes to be a good tender, if not objected to at the time [citing Wright v. Reed, 3 T. R. 554 (K. B. 1790)]. Certainly that was an innovation, though a beneficial one." Next followred Boardman v. Sill, 1 Camp. 410 n. (N. P. 180s), an action of trover with a refusal by the defendant to deliver, on the ground that the goods were his own property, and a defense, asserted later, that there was warehouse rent due the defendant. Lord Ellenborough said that as the detention was on a different ground, and no demand for the rent had been made, defendant must be taken to have waived his lien, if he had one. Then came Tiley v. Courtier, 2 C. \& J. 15, note (Ex. 1817) with a holding similar to Lockyer v. Jones, supra. In White v. Gainer, 2 Bing. N. C. 23 (C. P. 1824) Bet, C. J." while approving the case of Boardman v. Sill, supra, refused to apply its doctrine to the case where the defendant said, "If I deliver them I may as well give up every trancaction of my life" and later stated that if the lien had been settled he would have delivered. Best said that Boardman v. Sill, supra, applied only where the defendant gave a spacific reason for refusal at the time, as "It is my property."

46. 2 C. \& J. 14 (Ex. 1831); followed by Richardson v. Jackson, 8 MI. \& W. 297 (Ex. 1841), with a similar holding. Then in Flint v. Woodin, 9 Hare 618 (V. C. 1852), a Vendor and Purchaser case, the court said that a party to a contract becoming aware of an objection to the validity of the contract must state it forthwith as an objection on which he means to resist performance, or be considered to have waived it. Then came the first Sales case to involve the doctrine, Levy v. Green, 1 El. \& El. 969 (Ex. 1859). 
their "money-tender" precedents to the performance of a contract for the sale of goods. Thus in Levy v. Green, ${ }^{47}$ a defendant rejecting because of delay in shipment was allowed to defend on the ground that the goods shipped contained goods of a different description. In Manbre Saccharine Co., Ltd. v. Corn Products Co., Ltd. ${ }^{48}$ the court said that the plaintiffs were not, by the rejection of the tender on an insufficient ground, precluded from supporting the tender on other and valid grounds. The court in Taylor v. Oakes, Roncoroni \& Co., observed: "It is a long established rule of law that a contracting party who, after he has become entitled to refuse performance of his contractual obligations, gives a wrong reason for his refusal, does not thereby deprive himself of a justification which in fact existed, whether he was aware of it or not," and this principle applies to a contract for the sale of goods. ${ }^{.0}$

47. 1 El. \& El. 969 (Ex. Ch. 1859). This case was followed by Tamvaco v. Lucta, 1 B. \& S. 185 (Q. B. 1861), in which del credere agents, on tender of documents, denied being such, the price having fallen. At trial they set up defective tender as a defense. The court held tender was good, Cockburn, C. J., gratuitously adding that the defect was waived since remediable. In Sanders Bros. v. MacLean \& Co., 11 Q. B. D. 327 (1883), the court said that whether the reasons given at trial for rejecting two tenders of shipping documents were the true ones was unnecessary to determine, as, if they were legal reasons, defendant could rely on them. The court in Braithwaite v. Foreign Hardwood Co., [1905] 2 K, B. 543 , said that an absolute repudiation of the contract by $B$ before arrival of the goods amounted to a waiver of the performance of conditions precedent by $S$; and $B$ could not insist $S$ was unable to perform such conditions, and that if he had known the facts ho might have rejected the first installment of the goods upon their arrival. Mathew, L. J., said that in a business sense $B$ had no real cause for complaint. See the explanation of this case in Taylor v. Oakes, Roncoroni \& Co., 38 T. L. R. 349 (K. B. 1922). In the chartcrparty case of Furness, Withy \& Co. v. Rederiaktiegolabet Banco, [1917] 2 K. B. 873, an objection made for the first time at the trial was allowed by the court.

48. [1919] 1 K. B. 198. After replying, to plaintiff's demand, that they knew of no goods for plaintiff, defendants shipped anyway and forwarded invoices \& B/Ls dated March 14 which were refused on the ground the ship had been sunk March 12, and tho defendants must have known of it when they sent the invoices. In giving judgment for plaintiff, the court cited Sanders Bros. v. MacLean \& Co., 11 Q. B. D. 327 (1883), and Furness, Withy \& Co. v. Rederiaktiegolabet Banco, [1917] 2 K. B. 873, both citcd noto 47, supra.

49. 38 T. L. R. 349,351 (K. B. 1922). Rejection because customers refused delivery. After suit, defendant claimed goods were defective. Judgment for the plaintiff sinco the court found the goods were not far short of the contract quality, that but for a fall in the price they would have been accepted, and that the defect perhaps could have been remedied if made known. Braithwaite v. Foreign Hardwood Co., [1905] 2 K, B. 543, cited note 47 supra, was distinguished, in finding that the defense was not precluded for nonstatement, on the ground that that case dealt merely with an offer to hand over a bill of lading, and not with an actual tendered delivery, and that that was different from holding a breach already committed waived. In Hansson v. Hamel \& Horlcy, $10 \mathrm{Ll}$. L L. Rep. 507 (H. L. 1922), the court said that the reason why the buyers really refuscd the documents does not matter, nor did the case turn on the particular objection put forth by them at the time.

50. Note the tendency in the English cases to hold those who are trying to squirm 
The doctrine was imported from England into America through the "money-tender" cases and before the English Sales cases arose." There thus resulted the anomalous situation of the American courts relying on inapposite English precedents as authority for their holdings, while the English courts, with their usual judgment, refused to apply their own "money-tender" precedents to their Sales cases. The English courts apparently realized that different considerations applied to different situations. If $A$ refuses $B$ 's tender of money on the ground that it comes too late, and then, on finding that the tender was not too late, defends on the ground the money tendered was not legal tender, perhaps $A$ should be precluded from so defending on the theory that $B$ would have changed his money into legal tender and performed had that objection been made. We can make this assumption with far more certainty in such cases than we can in a Sales case, where a retender involves time, money, and a possibility of loss by depreciation. A retender of cash is much easier than a reshipment of 150 tons of iron; and it is safe to assume that a retender in the money case will almost always be made, and that it can be made within the necessary time. This historical anomaly, of utmost importance in any argument against the theory, has however nowhere been noted, either by protagonists or antagonists of the doctrine.

Starting out with the misapplication of the English "money-tender" cases in the New York case of Gould v. Banks \& Gould in 1832, rule continued unformulated for the most part till the very end of the nineteenth century. It is not until Littlejolin v. Shaw, in 1899, that the statement of the rule in the definite form in which it appears in that

out of their contracts, as in the cases of Tamvaco v. Lucas, 1 B. \& S. 185 (Q. B. 1861); Braithwaite v. Foreign Hardwood Co., [1905] 2 K. B. 543, both cited note 47, strpra; Manbre Saccharine Co. Ltd. v. Corn Products Co. Ltd., [1919] 1 K. B. 198, cited note 49, supra; and Taylor v. Oakes, Roncoroni \& Co., 38 T. L. R. 349 (K. B. 1922).

Australia too has followed the English view and refused to apply the doctrine. Mfacsey v. Arlitz (1923) 44 Aust. L. T. 145, noted (1924) 24 Cor. L. REv. 391.

51. Apparently the first case in the United States to apply the rule to the Sales situztion is Gould v. Banks \& Gould, 8 Wend. 562, 567 (N. Y. 1832), in which the court cבit that by putting his refusal to accept tender of books on the ground of unmerchantabiliti the plaintiff waived all other objections to the tender, such as previous failure to tender on time, and this, despite the fact that there was evidence that, unless the buyer's marlet was promptly supplied, it was gone. The court cited Wright v. Reed, 3 T. R. 554 (K. B 1790), cited supra note 43, and Grigby v. Oakes, 2 Bos. \& P. 526 (C. P. 1801), cited sujro note 45. One citation, 6 Bac. 450, could not be located. This case has been thought by many American courts to be the grandfather of the doctrine; and the fact that it, the first, rests on the English cases, supports the theory as to borrowing.

52. 8 Wend. 562 (N. Y. 1S32), cited note 51, stpra. The case might have been decided on the basis of an express waiver. By permitting a retender, though objecting to it on some other ground, the buy'er might be considered to have expressly waived a previous failure to tender. 
case is found. ${ }^{53}$ The period previous to that was one of groping, in which certain courts sought to prevent the buyer from setting up the unstated defects at the time of trial. Many of these courts did so because of a peculiar fact situation, as where there was apparently an express waiver, ${ }^{54}$ or where the court felt that the true objection was a drop in the market price. ${ }^{55}$ Others did so because of a feeling that the buyer in withholding all his objections was acting unfairly and really had no just complaint to make against the performance of the seller. ${ }^{50}$ Almost all the cases in this period are explicable on some ground other than the broad one that giving one reason is deemed to be a "waiver" of all others, or they enunciated some principle that was very different from the one voiced by Littlejohn v. Shawe. ${ }^{57}$ Note too that all during this period of hesitant growth many of the courts permitted the buyer to set up his unstated objections. ${ }^{58}$

It was towards the end of the nineteenth century that the scattered

53. See page 782, supra. Railway Co. v. McCarthy, 96 U. S. 258 (1877), had a definito statement of the rule, but it was not a Sales case. Its statement differed from that in Lilllejohn $v$. Shaw in that it stressed the commencement of litigation and the theory of estoppel. Railway Co. v. McCarthy, moreover, was never cited as authority in a Sales case till after the decision in Littlejohn $v$. Shaw, so that the statement to which this is the footnoto is technically correct, limited as it is to Sales cases.

54. Gould v. Banks \& Gould, 8 Wend. 562 (N. Y. 1832); Downer v. Thompson, 6 Hill 208 (N. Y. 1843). Strong, S., said that in the letter rejecting, under advice of counsel, only for bad quality there was express compliance as to the unstated defect.

55. Downer v. Thompson, 6 Hill 208 (N. Y. 1843); Hayden v. Demets, 53 N. Y. 426 (1873).

56. Meincke v. Falk, 61 Wis. 623,21 N. W. 785 (1884).

57. Sutton v. Risser, 104 Iowa 631, 74 N. W. 23 (1898) (court felt that the unstated defect was nonexistent anyway); Gould v. Banks \& Gould, 8 Wend. 562 (N. Y. 1832), cited note 52, supra; Downer v. Thompson, 6 Hill 208 (N. Y. 1843), cited note 54, supra; Hayden v. Demets, 53 N. Y. 426 (1873) (defect remediable); Smith v. Pettee, 70 N. Y. 13 (1877) ( $S$ could still have performed had the defect been noted); Knox v. Schoenthal, 59 Hun 620, 13 N. Y. Supp. 7 (Sup. Ct., 1891) (defect remediable if noted, says the court; substantial compliance as to defect); Germain Fruit Co. v. Roberts \& $\mathrm{Co}, 8 \mathrm{~Pa}$. Super. 500 (1898) (estoppel theory); Steeper v. Frieberg, Klein \& Co., 3 Civ. Cas. \& 240 (Tex. App. 1887) (objection not made in reasonable time).

58. Tascott v. Rosenthal, 10 Ill. App. 639 (1882), cited note 33, supra; Tufts v. McClure Bros., 40 Iowa 317 (1875), cited note 27, supra; Bryant v. Thesing, 46 Neb. 244, 64 N. W. 967 (1895); Newbery v. Furnival, 56 N. Y. 638 (1874), cited note 4, supra; Hill v. Heller, 27 Hun 416 (N. Y. 1882) ; Perry v. Mt. Hope Iron Co., 16 R. I. 318, 15 Atl. 87 (1888), cited note 30, supra; cf. Voorman v. Voight, 46 Cal. 392, 398 (1873) (rejection because price too high, and averment that packages were no good); Kaufman $v_{\text {, }}$ Austin \& Co., 57 Ga. 87 (1876) ; see Lefferts v. Weld, 167 Mass. 531, 536, 46 N. E. 107, 108 (1897); Everett v. Coffin \& Cartwright, 6 Wend. 603, 608 (N. Y. 1831) (proceeding on the basis that the defendant never put his right on a distinct scparate ground, but merely stated the facts, and that therefore there was no waiver of an unstated defense); O'Donohue v. Leggett, 55 Hun 607, 8 N. Y. Supp. 426, 430 (Sup. Ct. 1889), cited note 17, supra. 
statements of separate cases which had been decided on their particular facts began to coagulate to form a general rule. ${ }^{59}$ This clotting process culminated in the lower New York court dictum of Keswick v. Rafter, ${ }^{\circ}$ decided the year before Littlejolin v. Shaw. The former case was probably the inspiration for the disastrous dictum of the latter, which has provided the springboard for most of the cases which followed. The dictum of Littlejohn $v$. Shaw flourished like the green bay tree, ${ }^{01}$ and fostered meaningless citation ${ }^{62}$ which swamped the previous strong cases which had allowed the buyer to set up his unstated defects at the time of trial. ${ }^{63}$ This was because it cast its theory of conclusive presumption of waiver in the form of a definite, unmistakable rule, ${ }^{\text {of }}$ which could be easily maneuvered into position without the necessity of scrutinizing the fact situations of the cases too closely. ${ }^{65}$

But Littlejohn v. Shaw did not achieve its full stature unchallenged. As has been shown, from the earliest times there were cases difierently decided. $^{58}$ But these are not to be considered as challenges to that doctrine; they mark, rather, the attempt of the early cases to flow into another channel. Frustrated in that attempt they rushed into the bed of Littlejohn v. Shaw. Once they were there, fresh endeavors were made to

59. The first case to indicate the coagulation of the cases into a rule is that of Krox $v$. Schoenthal, 59 Fun 620, 13 N. Y. Supp. 7 (Sup. Ct. 1891). There the court said that when one objection is taken, and there is silence as to others, those others are deamed to be waived, on the theory that the other party has been misled by this silence. The nest case to state the rule in such definite terms was Germain Fruit Co. v. Roberts \& Co., 8 Pa. Super. 500 (1898).

60. 35 App. Div. 508, 513, 54 N. Y. Supp. 850, 854 (1st Dep't, 1898).

61. With variations: meaning those cases that place the theory on grounds of estoppal. notes 21 and 27 supra; those that stress the obviation of the defects, note 8 , sugra; and those that stress the commencement of litigation, note 11, supro.

63. In addition to being cited as a direct holding instead of a dictum, Liltlejolrs v. Shaw has frequently been said to lay down the same rule as Railway Co. v. McCarthy, 96 U. S. (1577), while we have seen, in note 53, supra, that the latter rule is more libaral. See in this connection Second Nat. Bank of Allegheny v. Lash Corp., 299 Fed. 371, 372 (C. C. A. 3d, 1924). Littlejolnz v. Shaw has also frequently been cited in relation to facts to which it has little or no bearing. See in this connection Pierson \& Co. v. Ameriean Steel Export Co., 194 App. Div. 555, 562, 185 N. Y. Supp. 527, 532 (1st Dep't, 1920); Keiser \& Son Co. v. Hallock, 201 App. Div. 186, 18s, 194 N. Y. Supp. 737, 739 (3d Dep't, 1922).

63. Tascott v. Rosenthal, 10 ml. App. 639 (1882); Tufts v. MicClure Bros., 40 Iome 317 (1875); Newbery v. Furnival, 56 N. Y. 638 (1874); Perry v. Mit. Hope Iron Con 16 R. I. 318, 15 Atl. 87 (1888).

64. See page 782, supra.

65. By this is meant that whereas previously the decisions of the courts were couched in terms of their individual facts ("In these circumstances the objection is waived"), the courts now had a general rule which could be used and cited without the necesity of comparing the case under consideration with the case cited to see whether there was a difference in their fact situations. 
dam the course at various times. Perhaps the earliest of these attempts was the case of Ungerer \& Co. v. Louis Maull Cheese \& Fish Co. ${ }^{00}$ a Missouri case decided in 1911, which disapproved of the general doctrine as laid down in the Littlejohn case and in its strongest immediate follower, Ginn v. Clark Coal Co. ${ }^{67}$ Since that time, the cases in Missouri have been decidedly against the prevailing rule. ${ }^{08}$ In New York, Strasbourger v. Leerburger, ${ }^{69}$ decided in 1922, marks a tendency away from the strict rule and has been followed in many of the later cases, although the law on this point in that state is by no means settled or uniform. ${ }^{70}$ There are some other states that have apparently never applied the "waiver" rule or that have overruled it; ${ }^{71}$ and all the various formulae for letting in defenses not discovered till after rejection eat small holes into the theory, so that some day its complete breakdown may result. ${ }^{\mathbf{2}}$

It is thus evident that there is very little historical justification for the doctrine of "waiver" of unstated defects. Arising from a misapplication of inapposite English precedents which the English courts later refused to follow, passing through a period when there were as many cases allowing the buyer to set up defenses not noted till trial as there were cases ruling the other way-these latter almost all distinguishable-the rule received its chief impetus from the unnecessarily extended ruling of Littlejohn v. Shaw. But in its later history it has been subjected to an increasing pressure of contrary holdings and modifications which bid fair to cause its downfall.

\section{IV}

\section{Relation to Price Movement}

Let us now subject to scrutiny the American cases which are believed

66. 155 Mo. App. 95, 134 S. W. 56 (1911), cited note 4, supra.

67. 143 Mich. 84,106 N. W. 867 (1906), cited note 6, supra.

68. Woldert Grocery Co. v. Pillman, 191 Mo. App. 15, 176 S. W. 457 (1915), cited note 30, supra; Fowler v. Cobb, 232 S. W. 1084 (Mo. App. 1921); Sabin Robbins Papdr Co. v. Cal Hirsch Mercantile Co., 263 S. W. 479 (Mo. App. 1924).

69. 233 N. Y. 55, 134 N. E. 834 (1922), cited note 8, supra.

70. The law in New York is, in fact, in hopeless confusion on this doctrine. It is possible to find strong cases supporting any theory as to when there is and when there is not a "waiver." The tendency, however, seems to be to work away from the rigid rule of Littlejohn v. Slzaw. O'Meara Co. v. Nat. Park Bank of New York, 239 N. Y. 386, 146 N. E. 636 (1925), proceeds as to this point on the theory that the defects could have been remedied if noted. It is, however, an unfortunate case in that it injects a certain amount of new life into what it was to be hoped was a dying rule. Sce in this connection Jardella v. Welin Davit \& Boat Corp., 219 App. Div. 353, 220 N. Y. Supp. 115 (2d Dep't, 1927). But cf. Hind v. Willich, 127 Misc. 355, 216 N. Y. Supp. 155 (Sup. Ct. 1926) (holding that some points made for defendant must be disregarded because the ground specified at the time of rejection must control the disposition of the case).

71. See note 30, supra. Here too might be cited the cases in note 27, supra.

72. See notes 31-35 inclusive, supra. 
by too many courts to have established beyond recall the mechanical, broad doctrine that unstated objections may not be relied upon at time of trial even though neither price drop nor any other element is present which might justify their exclusion. In analyzing these cases it must be remembered that on a rising market a buyer will seldom reject goods which are commercially in accordance with the contract, even though they do not conform strictly in law. The golden promise of profits induces acceptance of a legally defective performance. Rejections on such a market will occur chiefly when the performance is so defective as to make a profit impossible. On the other hand, a buyer will often try to escape from a performance quite within the business understanding of the contract, though not the legal, if he finds either that he can purchase the very same goods at a cheaper price on the open market or that his resale market has all but disappeared. The desire to avoid loss or to make greater profits overcomes the possible desire to be a "squareshooter" and to shoulder his part of that risk of price fluctuation which any present contract for future delivery carries, both for the seller, and for the buyer. In such a situation the buyer will often seize upon any excuse to avoid being forced to take the goods. This would, or should, naturally arouse in the courts a suspicion against reasons assigned only after litigation has commenced, or only after other reasons have been presented to the seller. It should arouse in them a desire to avoid allowing a business contract, entered with full knowledge of the price fluctuation risk, to be nullified because of commercially trivial reasons for rejecting. And delay in advancing reasons may be an index of triviality. Accordingly, it is justifiable to conclude that the factor of economic depression, where present, has been of considerable if not paramount influence in determining the result. In fact, in the absence of depression, many of the cases are entirely unjustifiable. It follows that those cases in which price drop can be shown to be present should not be regarded as precedent for unrestrained application of the rule of Littlejolin v. Shacw.

When an effort is made to determine just how many of the reported cases have contained this element of price decline as a possibly influential factor in the mind of the court, some difficulty is presented by those decisions in which there is no evidence that any drop in the market price had been brought to the court's attention. The handling of such cases necessitates the making of several presuppositions. ${ }^{73}$ (1) It must first of

73. It is arguable that none of these assumptions need be made; that all that needs to be investigated is whether a drop in the market or some other pivotal factor is present in these cases. But a mere agglomeration of data means nothing unless it can be used to indicate a possible explanation for the conclusion reached by the court. And the indication of that possible explanation involves the assumptions stated. There are a multilude of pivotal factors that might be investigated, such as the type of product, the type of transaction, etc.; but the particular factor of price decline was selected for serutiny be- 
all be assumed that the court has in some way learned of the market drop, because otherwise that lively suspicion which is so necessary to any desire to hold the buyer to the contract would possibly not be aroused. If the drop has occurred at a time of general financial, commercial, or industrial stress, it is safe to assume that the court will know of the drop in the same way that any layman would. But if the drop has occurred in this particular product only, and at a period when the general level of prices remained at that stage which may be termed "normal," it is safe to assume nothing in the absence of definite evidence. (2) However, passing beyond the bounds of safety and assuming that the court has knowledge of the drop of this particular product in an otherwise "normal" market, we must further assume that the court realizes the significance of this drop on the desire of the buyer to get out. ${ }^{74}$ Beyond the cases that specifically mention the falling market, the first assumption may be unwarranted; and outside of those that specifically say that the drop in the market was the real reason for rejection, it is likewise treading on dangerous ground to make the second assumption.

But all the necessary assumptions have not yet been stated. (3) Having supposed that the court has somehow learned of the drop in the market, that it realizes the significance of the drop on the buyer's actions, that it understands that pressure is likely to bring out a business man's real objections to the performance of the contract, and that these factors arouse in it a desire to prevent the buyer from squirming out of his con-

cause, of all possible pivots, this one would most clearly justify the cases if it be found to exist. Since this pivot ought to influence judicial decision, the fact that its existence is found to be present in a particular case indicates that it may have been $a$ reason or the reason why the decision went the way it did, even though the court did not make it the focal point of its argument. Thus the mere fact of its existence affords a ground for distinguishing away ostensibly binding precedents.

In investigating whether the element of price drop was present as one of the large group of factors which might have influenced a judge in any given case, it must also be remembered that a court moves of necessity in two time-planes: the time-plane of the contract and the breach, and the time-plane of the decision. It is easy to see that the business conditions of the former alone should influence the court; but trouble arises when we desert the "shoulds" and come to the "ises." Which influences a court more, a depression five years ago, or a depression to-day, a depression five years ago or boom timcs to-day, the boom times of 1927 or the depression of 1931? Which will color its decision more, a vague memory of market profits or the present reality of forgotten men? Without an exploration into the mind of the individual jurist, no one can tell. But it is one of the difficulties that must be faced, that perhaps the business conditions at the time of breach, especially if there is but a slight drop (though important enough to make it worthwhile to sue) in the specific product in an otherwise "normal" market, are overshadowed by those existing at the time of the decision.

74. Although this would appear to be a safe enough assumption, one cannot overlook the tendency of many courts to blind themselves to commercial realitieg in their preoccupation with mechanical legal abstractions. 
tract, yet fairness requires assuming further (a) that it realizes that business men are not lawyers and do not see precise legal objections, (b) that the rejection may have been made in haste, dispatched with the primary desire to make known the rejection and not the reasons for it, and that many things may be left unsaid in that hasty epistle in the honest belief that what has been stated is sufficient to justify the refusal to perform. (4) And to state a conclusion that it may possibly be because of the drop in the market that any given case has gone the way it has, it must be assumed that the latter elements are overbalanced by the former. ${ }^{75}$

All of this has been said to indicate the unsubstantial character of any conclusion that may possibly be reached; to show that the very extraction of a positive conclusion from the mass of data necessitates the use of these assumptions, none of which is capable of scientific handling. ${ }^{76}$

No attention will be paid to the cases which rule in favor of the buyer. Since the factor of depression, if it is present and if it operates at all, must work inevitably in favor of the seller, then, where these two conditions are fulfilled, some other element must be present to cause any case that goes for the buyer to be decided the way it is. And an examination of those cases mentioning a depression in price reveals, on the whole, the presence of such an element. ${ }^{7 \pi}$ Plain disgust with the

75. See note 73, supra.

76. In the subsequent discussion, four distinct types of ases will be perceptible. Typ? 1 consists of those cases in which the drop in the price of the commodity between the time of the contract and breach is considered by the court to be the real reason for the rejection. Here none of the assumptions is involved in the statement of a positive conclusion. Typa 2 encompasses those cases in which it is reasonably clear that the court feels that the drop in the market was the real reason for the rejection but it fails to say so explicitly. Here possibly the second assumption is involved in the conclusion. Type 3 consists of those cases in which the fall in the market price has been brought to the attention of the court but for some reason it fails to follow through. Here the second assumption is involved. The cases in Type 4 are those in which there is no evidence in the case that the court in any way knew of the fall in the price of the specific commodity or of the generally depressed business conditions at the time of breach, if such conditions were existent. In this lict type all the assumptions are involved in the statement of any positive conclusion. Certainly, too, the last assumption applies to all the cases.

77. Thus Williams Cooperage Co. v. Scofield, 115 Fed. 119 (C. C. A. Sth, 1902) (a refusal to ship by the seller with a rise in prices, working out the same way as a refucal to accept with a drop); Ungerer \& Co. v. Louis Maull Cheese \& Fish Co., 155 Mio. App. $95,134 \mathrm{~S}$. W. 56 (1911). In each there was a lack of knowledge of the defect by the defendant till after suit was brought. This is a powerful factor working for a ruling in the defendant's favor, more powerful than the forces working against him: the economic factor and other adverse elements in the fact situations. Western Grocer Co. v. New Yor: Oversea Co., 28 F. (2d) 518 (N. D. Cal. 1928), is partly explicable on this ground, and partly because the defect was not remediable. Outside of these, the others that rule in favor of the buyer are weak, and no principle can be drawn from them that would operste 
apparent unjustifiableness of the prevailing rule may of itself be sufficient at times to override even the economic force..$^{78}$

In the cases decided before Littlejohn v. Shaw, ${ }^{70}$ a falling market at the time of breach appears to be present in most of those ruling that the buyer cannot set up his unstated objections as defenses to the seller's suit. In two of them the economic factor was indicated and stressed by the court. In one case, Downer v. Thompson, ${ }^{80}$ a New York decision of 1843 , the court specifically says that the rejection was due to a drop in the market: "The fact which he admitted at the same time, viz. that he had already bought another lot at one or two shillings less per barrel indicates more probably the true objection." In Hayden v. Demets, the court said, "It is quite evident that the plaintiff was anxious to make the delivery, because the market price had fallen, and it is equally clear that the defendants desired to avoid the obligations of its contract for the same reason. . . [T] he transaction would have been closed at the time by paying the difference, but for a disagreement as to the price of copper on that day. It was too late after that to fall back on the insufficiency of the tender." 81 In this last case, the court speaks

against our conclusion. Indeed, the very fact that they are weak or contain factors countervailing the price drop lends that conclusion a strong negative support. See in this connection Young v. Rocha, 65 Cal. App. 15, 222 Pac. 861 (1923) (decided on the basis of the Callfor. nia statute); Kaufman v. Austin \& Co., 57 Ga. 87 (1876); Drew Co. v. Breedlove, 30 Ga. App. 722, 119 S. E. 532 (1923); Kieser \& Son Co. v. Hallock, 201 App. Div. 186, 194 N. Y. Supp. 737 (3d Dep't, 1922). These are apparently the only cases ruling for the buycr in which a price drop was mentioned. If the cases going for the buyer show a larger propurtion of decisions in which price drop is absent, this would be strong negative evidence in support of our premise that the economic factor, when known and present, influences the court, and it would thus support our conclusion that the rulings for the seller are not to be regarded as precedent in the absence of price drop or other justifying element. Sce notes 7, 24, 25, 27, supra.

78. See in this connection Ungerer \& Co. v. Louis Maull Cheese \& Fish Co., 155 Mo. App. 95, 134 S. W. 56 (1911); Fowler v. Cobb, 232 S. W. 1084 (Mo. App. 1921).

79. Littlejohn v. Shaw has been selected as one base-line for a consideration of the cases because, as has been shown previously, the bold form of the precedent received its chitef impetus from that case. Ginn v. Clark Coal Co. has been selected as another basc-line because that case marks what may be termed the high-water mark of this line of precedent. All that is necessary to enable us to draw a significant conclusion is a showing of the presence of the economic factor in most of the cases before Littlejohn v. Shaw. If that showing continues just as strongly in the cases before Ginn v. Clark Coal Co., it indicates that, instead of gathering weight and persuasiveness as precedent, the broad mechanical rulo has been able to muster no greater adherence (without the assistance of price drop or other justifying element) in this period than in that prior to the Littlejoln case. If the presence of market decline continues in equal proportion even into the modern cases, still greater force is added to the conclusion that the rigid waiver rule has not by its own virtue succeeded in establishing itself as binding precedent.

80. Hopkins, Senator, in 6 Hill 208, 212 (N. X. 1843), cited note 54, supra.

81. Church, C. J., in 53 N. Y. $426,428,430$ (1873) (rejection for inability to pay). 
of the fall in such a way that it is reasonably clear that in its belief the drop was the real reason for the breach and that that belief was a spur to its desire to hold the buyer.

In the remaining cases in this period in which the buyer was precluded from setting up his unstated objections, there is no indication in the case itself of any drop in the market price of the specific commodity or of generally depressed business conditions at the time of breach. ${ }^{82}$ But in

82. In considering the cases, the following weather barometer of American business history from 1818 will be used. The form of the chart and most of the information was derived from Orro C. LightNen, Histony of Busaness Depressions (1922). The other information was gathered from Irving Fismer, Booses Ard Depressions (1932) and Arruzun B. Adazas, Trend of Busniess, 1922-32 (1932).

\begin{tabular}{|c|c|c|}
\hline 1818-Threatening & 1857-Tornado & 1597-Fair \\
\hline 1819-Hurricane & 1858-Clearing & 1898-Fair \\
\hline 1820 -Gale & 1S59-Fair & 1399-Fair \\
\hline 1821-Clearing & 1s60-Storm & 1900-Fair \\
\hline 1822-Fair & 1861-Stormy & 1901-Fuir \\
\hline 1823-Fair & 1S62-Fair & 1902-Fair \\
\hline 1824-Fair & 1863-Fair & 1903-Squall \\
\hline 1825-Storm & 1S64-Fair & 1904-Fair \\
\hline 1826-Fair & 1865-Fair & 1905-Fair \\
\hline 1827-Fair & 1866-Fair & 1906-Fair \\
\hline 1828-Squall & 1867-Fair & 1907-Cyclone \\
\hline 1829-Fair & 186S-Threatening & 190s-Clearing \\
\hline 1830-Fair & 1869-Black Friday & 1909-Fair \\
\hline 1831-Fair & 1870-Fair & 1910-Fair \\
\hline 1832-Fair & 1871-Fair & 1911-Fair \\
\hline 1833-Partly Cloudy & 1872-Fair & 1912-Fair \\
\hline 1834-Fair & 1873-Cyclone & 1913-Partiy Cloudy \\
\hline 1835-Fair & 1S74-High Winds & 1914-Storm \\
\hline 1836-Threatening & 1875-Clearing & 1915-Partly Cloudy \\
\hline 1837-Hurricane & 1876-Fair & 1916-Fair \\
\hline 1838-Stormy & 1S77-Fair & 1917-Fair \\
\hline 1S39-Continued Stormy & 1878-Storm & 1918-Fair \\
\hline 1840-Clearing & 1879-Clearing & 1919-Fair \\
\hline 1841--Fair & 1880-Fair & 1920-Partly Cloudy \\
\hline 1842-Fair & 1882-Fair & 1921-Stormy \\
\hline 1843-Fair & 1883-Partly Cloudy & 1922-Stormy \\
\hline 1844-Fair & 18s4-Storm & 1923-Fair \\
\hline 1845-Fair & 1835-Fair & 1924-Fair \\
\hline 1846-Fair & 1886-Fair & 1925-Fair \\
\hline 1847 -Storm & 1837-Fair & 1926-Fair \\
\hline 1848-Storm & 1888-Fair & 1927-Fair \\
\hline 1849-Fair & 1889-Threatening & 1928-Threstening \\
\hline 1850-Fair & 1890-Storm & 1929-Eurriane \\
\hline 1851-Squall & 1891-Fair & 1930-Hurricane \\
\hline 1852-Fair & 1892-Fair & 1931-Stormy \\
\hline 1853-Fair & 1893-Storm & 1932-Stormy \\
\hline 1854-Fair & 1894-Stormy & 1933-Stormy \\
\hline 1855-Fair & 1895-Continued Stormy & 1934-Stormy \\
\hline 1856-Fair & 1896-Clearing & \\
\hline
\end{tabular}


by far the majority of the cases in which the date of breach is given, the breach did in fact occur at a time of general business stress or when there was a drop in the price of the specific commodity. ${ }^{83}$ In one case in which no date of the breach is given, there was some evidence, though not clearly brought out, of a declining market, or at least of a fluctuating market in the product, with the court unwilling to throw its risk on the seller; ${ }^{84}$ in another, there was apparently a feeling on the part of the court that the buyer was acting in bad faith. ${ }^{85}$ And in the two cases in

83. Name of Case Business Conditions at Business Conditions at Tinto Time of Breach. of Decision.

Manner of Price Fhuchua- Source of Information. tion of Specific Commodity Between Dates of Contract and Breach.

Gould v. Banks \& Gould, 8

Wend. 562 (N. Y. 1832)

Smith v. Pettee, 70 N. Y. 13 (1877)

Meincke v. Falk, 61 Wis. 623, 21 N. W. 785 (1884)

Knox v. Schoenthal, 59 Hun 620,13 N. Y. Supp. 7 (Sup. Ct. 1891)

Keswick v. Rafter, 35 App. Div. 508, 513, 54 N. X. Supp. 850, 854 (1st Dep't, 1898) d.

Germain Fruit Co. v. Roberts \& $\mathrm{Co}$., $8 \mathrm{~Pa}$. Super. 500 (1898)

Sutton v. Risser, 104 Iowa 631, 74 N. W. 23 (1898)

Weill v. American Metal Co., 182 III. 128,54 N. E. 1050 (1899)

Littlejohn v. Shaw, 159 N. Y. 188,53 N. E. 810 (1899)

A small "d" after a case indicates a dictum.

Weill v. American Metal Co., supra, is still further bolstered by the fact that the buyer demanded a lower price. It is interesting to trace throughout this section the growth of the New York cases, to note how often a case which rules for the seller and in which the breach occurred in fair times has followed a case in which the breach occurred in a time of business stress, and how this gradually hardens into a line of ostensible precedent.

84. Keswick v. Rafter, 35 App. Div. 508, 513, 54 N. Y. Supp. 850, 854 (1898).

85. Meincke v. Falk, 61 Wis. 623,21 N. W. 785 (1884).
Fair

Case itself.

Fair

Storm

Fair

Fair

Case itself.

Fair

Bull, of Dept. Labor, Jan.

Nov. 1900, Nos. 26-31, p.

Fair

Op. cit. supra, at 252.

Fair

Op. cit. sutpra, at 300 and 303.

Fair 
this period in which the breach occurred in "normal" times, the court laid down a less rigid form of the rule, basing its holding on the theory of the possibility of the obviation of the defect. ${ }^{80}$ The breach in the case of Littlejohn $v$. Shaw itself occurred at a time of general business stress. We can, accordingly, infer that in all but a very few of the cases before Littlejohn v. Shaw probably one reason (and probably the most important one) why the buyer was precluded from setting up his unstated objections was the fact that he was rejecting on a falling market and that the court was unwilling to permit him to escape from the contract in these circumstances. ${ }^{87}$

In the cases between Littlejohn v. Shaw and Ginnz v. Clark, we find a difference of alignment under a falling market, depending on whether the theory of the case is the same as that of these two cases or is some other rule that is less rigid. 88 In the cases that strictly follow the "waiver" rule of the Littlejohn case, the ruling in most is accompanied by breach in time of business stress or after drop in price of the specific commodity. In one of them, Peterson Bros. v. Mineral King Fruit Co., ${ }^{\$ 3}$ there was evidence by the buyer that had the market not gone down he would have accepted, and that on a rising market he could put goods through which he could not on a falling market. In another, an Illinois case of 1904, the buyer had offered to take the goods at a lower price, to which the seller had replied that he could not protect the buyer against a glutted market. ${ }^{90}$ It is unfortunate that in these cases, and in all cases where the buyer states in his letter of rejection that he will not take the goods because the price has gone down, because he is unable to pay, or because of generally poor business conditions, the courts so seldom stress that the other reasons which the buyer later seeks to set up are probably unwarranted excuses to escape from a losing bargain, but lay

86. Smith v. Pettee, 70 N. Y. 13 (1877); Knox v. Schoentbal, 59 Hun 620, 13 N. Y. Supp. 7 (Sup. Ct. 1891). Estoppel is a "less rigid" form of the rule than waiver because, while the theory of the latter is such that it is very likely to be treated as absolute, the theory of the former is such that it will often be invoked only after the court has made some examination of the factual set-up to see if there has been some sort of inducement to reasonable action in reliance to damage. And we have seen that a large majority of the cases that use the estoppel theory decide for the buyer. See note 27, supro. And soe the text accompanying notes 21-29, supra.

87. See page 801, supra.

88. E.g., estoppel, stressing the commencement of litigation or the possibility of obvinting the defect. See note 86, supra. The emphasis here is not so much on variations in fact situations as on what the court says. As to some of the more doubtful cases, there is room for difference of opinion as to manner of classification. But their number is slight. Some of the cases used in this section are dicta, but their cumulative effect, especially when taken in connection with a falling market, make them sufficiently important to be included.

89. 140 Cal. 624, 74 Pac. 162 (1903).

90. Olcese v. Mobile Fruit \& Trading Co., 112 III. App. 281 (1904). 
down an over-broad rule which has no relation to the facts-a rule which can be applied even in the absence of a depressed market. The results are usually sane on their facts. But by failing to relate certain material facts more integrally to the rule of law, the court leaves open to future courts a temptation to extend the rule beyond its sane limits.

In still another case in this period which followed the "waiver" theory, the transactions and breach occurred at times when business conditions were generally poor or were just beginning slightly to improve from a previously depressed state. The constant bickerings as to price, related in the report, also reveal some downward trend in the market price for the specific commodity. ${ }^{01}$ In the last case following apparently, though not specifically, that theory, there is some external evidence of a drop in the particular product. That this was the real reason for rejection is further buttressed by the presence of constant price revision, and by the willingness of the seller to agree to a lower price up to a certain point. ${ }^{\text {es }}$ The breach of Ginn v. Clark Coal Co. itself, however, occurred at a time when the price of the specific commodity was rising and in a period of "normal" business activity.93 The decision in that case, forbidding the setting up of unstated objections, exemplifies mechanical application of the "waiver" rule to a situation where neither equitable nor economic justification for it existed.

In the rest of the cases in this period the breach occurred in times that may be termed "normal," and the movement of the specific prices seemed to bear out on the whole the trend of the general market. ${ }^{04}$ But

91. Manda v. Etienne, 93 App. Div. 609, 611, 87 N. Y. Supp. 588, 593 (1st Dep't, 1904), cited note 12, supra.

92. Drucklieb v. Universal Tobacco Co, 106 App. Div. 470, 94 N. Y. Supp. 777 (1st Dep't, 1905).

93. 143 Mich. 84, 106 N. W. 867 (1906), see infra note 94.

94. Name of Case

$\begin{array}{ll}\text { Business Conditions at } & \text { Business Conditions at } \\ \text { Time of Breach. } & \text { Time of Decision. } \\ \text { Manner of Price Fhuctua- } & \text { Source of Information. } \\ \text { tion of Specific Commodity } & \\ \text { Between Dates of Contract } & \\ \text { and Breach. } & \end{array}$

'Oakland Sugar Mill Co. v. Fair (1899-00) Wolf Co., 118 Fed. 239 (C. C. Steady (Sugar) A. 6th, 1902)

air $(1899-00)$
Steady (Sugar)

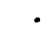

Peterson Bros. v. Mineral King Fruit Co., 140 Cal. 624, 74 Pac. 162 (1903)

Rochevot v. Wolf, 96 App. Div. 506, 89 N. Y. Supp. 142

(4th Dep't, 1904)
Fair

Bull. Dept. Labor, Jan.Nov. 1900, Nos. 26-31, pp. 287-288. Jan.-Nov, 1902, Nos. $38-43$, p. 332.

Squall

Fair 
it is interesting to note that each of these cases stated some theory that was not strictly that of Littlejolin $v$. Shaw, proceeding instead on the basis of some form of estoppel.95 This would seem to indicate that, where the economic factor is absent, some more justifiable ground than the empty formalism of the "waiver" rule is required in order to produce a ruling against the buyer. ${ }^{88}$ Thus additional strength is afforded the belief that few if any, of these cases between Littlejolin $v$. Shaw and Ginn v. Clark Coal Co. should be accorded any weight as precedent for the general proposition that unstated objections may never be set up at trial even though the factual situation discloses neither price drop nor any other factor which might give at least a semblance of equitable justification for a decision adverse to the buyer. ${ }^{00}$

In those cases decided adversely to the buyer subsequent to Ginn v. Clark Coal Co., one would expect to find a larger number of situations not containing the element of price decline. One would expect that the force of precedent would by now have become so great that the factor of depression would be but rarely needed to motivate a ruling against the buyer. It is then with some relish to be noted that despite Littlejohn v. Shaw, and even with Gimn v. Clark Coal Co. on the books, fully as large a proportion of the cases after the Ginn case contain the economic factor as before. ${ }^{97}$ This would seem to indicate

\footnotetext{
United Fruit Co. v. Bisese, Fair (1902) Fair

$25 \mathrm{~Pa}$. Super. 170 (1904) Steady (Fruit)

U. S. Bur. Lubor Statistics

Vol. 8, p. 256.

Manda v. Etienne, 93 App.

Div. 609, 611, 87 N. Y. Supp.

588, 593 (1st Dep't, 1904)

Continued Stormy-Clearing Fair

(1895-6) Case itself.

Fall (flower bulbs)

Olcese v. Mobile Fruit \& Storm (1893)

Trading Co., 112 Ml. App. 281

(1904)

Drucklieb v. Universal Tobacco Co, 106 App. Div. 470, 94 N. Y. Supp. 777 (1st

Dep't, 1905)

Ginn v. Clark, 143 Mich. 84, 106 N. W. 867 (1906)

Storm (1893) Fair

Fair (1901)

Probably fall (tobacco) Fair

Cace itself and Bull. Dept. Labor, Jan.-Nov. 1902, Nos. $38-43$, pp. $454-455$.

Fair (1902) - Fair

95. Oakland Sugar Atill Co. v. Wolf Co., 118 Fed. 239 (C. C. A. 6th, 1902); Rochevot v. Wolf, 96 App. Div, 506, 89 N. Y. Supp. 142 (4th Dep't, 1904); United Fruit Co. v. Bisese, $25 \mathrm{~Pa}$. Super. Ct. 170 (1904).

96. Ginn v. Clark Coal Co. itself was decided with such blind subservience to precedent [see the second opinion, 143 Mich. 88, 107 N. W. 904 (1906)] that it can hardly be regarded as "authority."

97. In some of these cases there is evidence that the seller has resold at a price lowar than the contract price, but this of course indicates less than appenrs on the surface. The
} 
that the broad rule against setting up unstated defects has not succeeded in strengthening its position as precedent ${ }^{70}$ where price decline or one of the other justifying elements is not present. ${ }^{08}$

First let us look at the cases which have used the language of "waiver." In four of these cases, not only was a price drop evident, but the courts talked about it in language which indicated that this factor seemed to them material. In Daniels v. Morris, it was said,

"Prior to October the price of hops had gone down ... . so that at the time the hops were tendered ... plaintiffs were anxious to be relieved from taking the [m] ... [Whether these were choice hops] depends upon the opinion of the person judging, rather than on any accurately definable conditions. . . Opinions differ. . . The demand and price for the hops are subject to sudden and extreme fluctuations without apparent reason; and, when a person makes such a contract, he cannot expect the courts to show him leniency because of its hardships when the price is adverse to him."

A Virginia court in 1925 said, "It seems plain from the evidence as a whole that Fielding declined because of the fall in the market, but he based his claim on the ground that his contract called for November delivery, instead of November shipment. .."100 In the same year an Illinois court gave voice to the same sentiment;

"When the shipments arrived in July a tender was made to the defendant, but refused, and diligent efforts by the plaintiff were insufficient to obtain a statement of its reasons for such refusal. We are not, however, left in darkness: the continually falling market price for this product illumines the situation. And that the decline in price was the reason was established not only by oral evidence but by mutual correspondence between the parties .... "101

And a Nebraska case of 1912 even went so far as to declare that " . . it was proper for the trial court to take into consideration judicial knowledge that there was a general depression in business after the goods were delivered to the carrier .... and the fact that financial conditions, arising unexpectedly after the goods were purchased, led to defendant's attempt to countermand the orders." 102

goods may have been damaged in some way; the seller may have been pressed for time, because the goods were depreciating or for some other reason, and had to get rid of them to the first buyer who offered less than the prevailing price. An assumption has not been felt warranted that merely because the seller resold at a price lower than the market or contract price, that there had been a drop in the general market price for this product.

98. See notes $7,24,25,27$, supra.

99. 65 Ore. 289, 295, 130 Pac. 397, 399 (1913) (objection of overweight precluded, for not only was there insufficient evidence of it, but objection not made at time of rejection).

100. See Fielding v. Robertson, 141 Va. 123, 131, 126 S. E. 231, 233 (1925) (rejection because customers refused to take, and defect remediable; held, no waiver becauso no knowledge, but estoppel). We have included the case here instead of in the obviation section because of its strength, and because such inclusion does not prejudice the analysis.

101. See National Importing \& Trading Co. v. Bear \& Co., 236 Ill. App. 426, 440 (1925) (a rejection stated generally held waived).

102. Rose, J. in Armsby Co. v. Raymond Bros.-Clarke Co., 90 Neb. 553, 561, 134 N. W. 174, 177 (1912), cited note 5, supra. 
In Lowinson v. Newman, the court said, "The market price of the goods covered by the contract had declined some two cents per yard. Suppose that the market had risen, was there [anything in the rejection] which would have relieved the plaintiff from completing his contract. ...? Most assuredly not."103 The court here realized that had there been a rising market something different would have happened. But it fails to push that awareness to the point where it takes on rule-form, and can be carried to its logical conclusion. A similar feeling is experienced in the reading of a case like Harvard Co. $v$. Hinnmelein, ${ }^{104}$ in which the original rejection was based on the ground that customers refused delivery.

There are other cases where the drop in the market is so pronounced that the failure of the court to stress this in words as probably the real reason for rejection is almost unforgivable. Among these are the sugar cases of 1920, when the post-war price disintegration took almost unprecedented toll on those who had contracted into the future. One case among these mentions a drop from $233 / 4 \%$ to $61 / 4 \%$ per pound, and nevertheless does not seem to realize what this means to the buyer's performance. ${ }^{105}$ Another, though giving a slight indication that the court knew of the drop in the market, nowhere specifically mentions the collapse and fails utterly to indicate its effects. ${ }^{100}$ Then there are several cases where the buyer states in the letter of rejection which he sends to the seller that he will not take the goods because the price has gone down, or because he is unable to pay, or because of generally poor business conditions. ${ }^{107}$ In four remaining cases in which there is evidence that the drop in the price of the specific product was known to the court, there is nevertheless no stressing, either in the facts or in the opinion, of the now patent fact that this may have been the real reason for rejection. ${ }^{103}$ It is interesting to note that by far the greater

103. 201 App. Div. 266, 270, 194 N. Y. Supp. 253, 256-257 (1st Dep't, 1922).

104. 226 Mich. 691, 198 N. W. 207 (1924), cited note 6, supra.

105. Colonial Ice Cream Co. v. Interocean IFercantile Corp., 296 Fed. 316, 319 (C. C. A. 3d, 1924) (stressing the fact that the unstated defenses were not raiced once before the appeal, and that $B$ was trying to avail himself of unsubstantial technical objections; the verbal attitude being in favor of "the rule" of Littlejolrs v. Shaw and, pardonably cnougb so cited in Erie Food Products Corp. v. Interocean Miercantile Corp., 299 Fed. 71 (C. C. A. 6th, 1924).

106. Erie Food Products Co. v. Interocean Mfercantile Corp., 299 Fed. 71 (C. C. A. 6th, 1924) ("technical" insufficiency of tender precluded as a defense).

107. Memhard v. Gabrielsen Co., 224 Ky. 238, 5 S. W. (2d) 1070 (1928) (inability to pay; other reasons were insufficient and also waived because of nonstatement); see Higgirs v. California Prune \& Apricot Growers, 16 F. (2d) 190, 192 (C. C. A. 2d, 1926) (rejection unless price revised); E. L. Rice \& Co. v. Roberts, 172 S. E. 615, 616 (W. Va. 1934), cited note 12, supra. Refer in this connection to pages S07-SOS, supra.

108. Rand v. Morse, 289 Fed. 339 (C. C. A. Sth, 1923) (if the jury found there was knowledge of unstated defect they could find waiver on the principle that one sattica 
number of the breaches in all these cases, from our discussion of Daniels v. Morris on, occurred in times of generally depressed business conditions. ${ }^{109}$

up specific defenses cannot resort to others when sued); Chatham Ice Cream Co, v. Sakakeeny, 29 Ga. App. 768, 116 S. E. 558 (1923) [Facts in 27 Ga. App. 409, 108 S. E. 802 (1921) ]; Carson Petroleum Co. v. Balboa Trading Co., 120 Misc. 389, 198 N. Y. Supp. 556 (Sup. Ct. 1923); see Garcia \& Maggini Co. v. Washington Dehydrated Food Co., 294 Fed. 765,768 (C. C. A. 9th, 1924).

109. Name of Case

Armsby Co. v. Raymond Bros-Clarke Co., 90 Neb. 553, 134 N. W. 174 (1912)

Daniels v. Morris, 65 Ore. 289, 295, 130 Pac. 397, 399 (1913)

Chatham Ice Cream Co. v. Sakakeeny, 29 Ga. App. 768, 116 S. E. 558 (1923)

Lowinson v. Newman, 201 App. Div. 266, 194 N. Y. Supp. 253 (1st Dep't, 1922)

Rand v. Morse, 289 Fed. 339 (C. C. A. 8 th, 1923)

Carson Petroleum Co. v. Balboa Trading Co., 120 Misc. 389, 198 N. Y. Supp. 556 (Sup. Ct. 1923)

Harvard v. Himmelein, 226 Mich. 691, 198 N. W. 207 (1924)

Colonial Ice Cream Co. v. Interocean Mercantile Corp., 296 Fed. 316, 319 (C. C. A. 3d, 1924)

Erie Food Products Corp. v. Interocean Mercantile Corp., 299 Fed. 71 (C. C. A. 6th, 1924)

Garcia \& Maggini Co. v. Washington Dehydrated Food Co., 294 Fed. 765, 768 (C. C. A. 9th, 1924)

Fielding v. Robertson, 141 Va. 123, 126 S. E. 231 (1925).

National Importing \& Trading Co v. Bear \& Co., 236 III. App. 426 (1925)
Business Conditions at Time of Breach.

Cyclone (1907)

Fair (1910)

Partly Cloudy

Fair-Partly Cloudy (1919-20)

Fair (1918)

Business Conditions at Time of Decision.

Fair

Stormy

Stormy

Fair

Partly Cloudy (1920)

Fair

Partly Cloudy (1920)

Fair

Stormy (1921)

Fair

Partly Cloudy (1920)

Fair

Partly Cloudy (1920)

Fair

Partly Cloudy (1920)

Fair

Partly Cloudy (1920)

Fair 
There remains a group of cases in which there is no evidence that any price drop was known to the court. ${ }^{110}$ In one-third of these, as

Higgins v. California Prune \& Apricot Growers, 16 F. (2d) 190, 192 (C. C. A. 2d, 1926). Memhard v. Gabrielsen Co., $224 \mathrm{Ky} .238,5$ S. W. (2d) 1070 (1928)

E. I. Rice \& Co. v. Roberts, 172 S. E. 615, 616 (W. Va. 1934)

110. Name of Case

Hess v. Kaufherr, 128 App. Div. 526, 112 N. Y. Supp. 832 (1st Dep't, 1908)

Providence Jewelry Co. v. Bailey, 159 Nlich. 285, $123 \mathrm{~N}$. W. 1117 (1909)

Lorraine Mfg. Co. v. Oshinsky, 182 Fed. 407 (C. C. S. D. N. Y. 1910)

Honesdale Ice Co. v. Lake Ladore Improvement Co., $232 \mathrm{~Pa} .293,81$ Atl. 306 (1911)

Cary Maple Sugar Co. v. Pierre Viau Maple Co., 173 III. App. 93 (1912)

Howe Grain \& Mercantile Co. v. Taylor, 147 S. W. 656,658 (Tex. Civ. App. 1912)

Mills v. Knickerbocker Hat Co., 76 Misc. 446, 135 N. Y. Supp. 5 (Sup. Ct. 1912)

Linger v. Wilson, $73 \mathrm{~W}$. Va. 669,80 S. E. 1108 (1914)

Foster Drug Co. v. Zeller \& Sons Co., 191 IIl. App. 50S (1915)

De Hofi v. Aspegren, 96 Misc. 681, 161 N. Y. Supp. 53 (Sup. Ct. 1916)
Stormy (1921)

Fair

Partly Cloudy (1920)

Threatening

Stormy (1932)

Stormy

Business Conditions at Time Business Condilions af Time of Breach. Manner of Price Fluctuation of Specific Commodity Between Dates of Contract and Breacls.

Cyclone (1907)

of Decision.

Source of Information.

Cyclone (1907)

Fair

Fair

Clearing-Fair (1905-9)

Fair
Fair (1909)
Steady (Sugar)

Fair (1910)

Fair (1910)

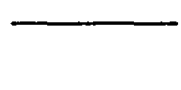

Fair (1911-2)

Partly Cloudy-Fair (1915-16) Fair

Steady and up (apples)
Fair

Bull. Dept. Labor, Vol. 20, pp. 545-50. (Wh'sale Commodity Price Indes).

Fair

Fair

Storm

Partly Cloudy
U. S. Bur. Iator Statisties, Wh'sale Commodity Prices, Bull. 11s1, p. 39. 
appears from the footnote, irrespective of evidence as to what the court knew, the factor of depression was present. The apparent problem raised by the remaining two-thirds in which the breach occurred in "normal" times fades into insignificance when it is seen that in the entire group of "waiver" cases after Ginn v. Clark, about two-thirds of the breaches still prove to have occurred in times of generally depressed business conditions or when the price of the specific commodity has fallen.

Similarly, in the group of cases that stresses, in its explicit theory, the fact that the unstated defect was not made known until after litigation had commenced, the economic factor of price decline is present in most as a possibly contributing or even determining element. For example, in a Federal District Court case of 1925 the court said,

Pierson \& Co. v. American Steel Export Co., 194 App. Div. 555, 562, 185 N. Y. Supp. 527, 532 (1st Dep't, 1920)

Tuggle v. Green \& Sons, 150 Ga. 361, 104 S. E. 85 (1920)

Robertson v. Garvan, 270 Fed. 643 (S. D. N. Y. 1920)

Baruch v. Dery, 188 N. Y. Supp. 453 (Sup. Ct. 1921)

Internat. Banking Corp. v. Irving Nat. Bank, 274 Fed. 122 (S. D. N. Y. 1921)

Bank of America v. Whitney Central Nat. Bank, 291 Fed. 929 (C. C. A. 5th, 1923)

Bank of Taiwan v. Union Nat. Bank of Philadelphia, 1 F. (2d) 65 (C. C. A. 3d, 1924)

Hind v. Willich, 127 Misc. 355,216 N. Y. Supp. 155 (Sup. Ct. 1926)

Schulze Baking Co. v. Goodson, 119 So. 353 (Miss. 1928)

Popper v. Rosen, $292 \mathrm{~Pa} .122$, 140 Atl. 774 (1928)

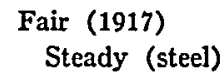

Fair (1916)

Storm-Partly Cloudy (1914-5) Up (zinc crude)

Fair (1918) Steady (cloth)

Fair-Partly Cloudy (1918-20) Stormy Fall (Jap. silk)

Partly Cloudy (1920) Fall (Sugar)

Partly Cloudy (1920) Fall (copra)

Fair (1926)

Fair (1926) Steady (glass)
Partly Cloudy

Op. cit. supra. Bull. 269, p. 112 .

Partly Cloudy

Partly Cloudy Case itself.

Stormy

Op. cit. supra. Bull. 269, pp. 70-97

Op. cit. supra. Bull, 269, p. 86. Bull. 296, p. 132. Fair

Second National Bank of Allegheny v. Lash Corp., 299 Fed. 371 (C. C. A. 3d, 1924)

Fair

Young v. Rocha, $65 \mathrm{Cal}$. App. 15, 222 Pac. 861 (1923)

Fair

Threatening

Threatening

U. S. Bureau Labor Statistics, Wh'sale Prices, Bully. 390, 415, 440, 458, p. 171. 
"It is, of course, a fact that toward the end of that year [1920] there was the greatest fall in the price of staples in the history of civilization. And on the whole I cannot avoid the conclusion that this contract, on the part of the defendant, was a mere 'leap in the dark'. . . It arrived upon a glutted and falling market, and it was contracted for at a time when American buyers were feverishly contending with one another for any kind of sugar. . . The delay in shipping the second cargo had nothing whatever to do with the rejection. On the contrary, the evidence fairly justifies the conclusion that the defendant contracted for an article not readily saleable in this market, and that the rejection was due to the discovery of this fact, coupled with a falling market."111

This language was quoted with approval on appeal. ${ }^{112}$ In another case the buyer stated in his letter of rejection that the price was too high and that he would take only at a lower price. ${ }^{113}$ In the remaining cases in this section, those in which there is no explicit evidence that the court knew of the price drop or of a generally depressed market at the time of breach, these factors were in fact present in about half. ${ }^{11}$

111. Partridge, J. in Mathieu v. Geo. A. Moore \& Co., 4 F. (2d) 251, 253, 255 (N. D. Cal. 1925).

112. Geo. A. Moore \& Co. v. Mathieu, 13 F. (2d) 747 (C. C. A. 9th, 1926).

113. Cobb Lumber Co. v. Sunny South Grain Co., 36 Ga. App. 140, 135 S. E. 759 (1926).

114. Name of Case

Business Conditions at

Time of Breacls.

Mamer of Price Fluctuation of Specific Commodity Between Dates of Contraet and Breacls.

Fair (1904)

Business Conditions at Time of Decision.

Source of Information.

Bedingfield \& Co. v. Bates Advertising Co., 2 Ga. App. 107, 58 S. E. 320 (1907)

Polson Logging Co. v. Neumever, 229 Fed. 705 (C. C. A. 9th, 1916)

Fruit Dispatch Co. v. Petropol, 25 Ga. App. 839, 105 S E. 48,49 (1920)

Cadick Milling v. Voldosta Grocery Co., 72 Ind. App. 534, 126 N. E. 240 (1920)

Wall Grocer Co. v. Jobbers' Overall Co., 264 Fed. 71 (C. C. A. 4th, 1920)

Godchaux Sugars Inc. v. Meridian Wholesale Co., 289 Fed. 359 (C. C. A. 5th, 1923)

Frank \& Meyer Neckwear Co. v. White, $29 \mathrm{Ga}$. App. 694, 116 S. E. 855 (1923)

\section{Fair (1912) Steady (steel)}

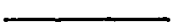

Storm-Partly Cloudy (1914-5)

Fair (1917)

Upp (denims)

Partly Cloudy (1920)

Fall (sugar) (1920-1)
Partly Cloudy-Stormy
Fair

U. S. Bureau Lator Statictics. Wh'esle Prices No. I (1890-1912) p. 80

Partly Cloudy

Partly Cloudy

Partly Cloudy

Case itcalf and op. cit. supro. Bull. 269, p. 74

Fair

Second National Banls of Allegheny v. Lash Corp., 299 Fed. 371 (C. C. A. 3d 1924).

Fair 
In the cases that place their theory on some other form of estoppel, such as the possibility of obviating the defects had timely notice been given, the economic factor is likewise usually present. In Griffin Grocery Co. v. Richardson it was said, "The proof showed that there was a marked decline in the price of seed between the time the contracts were made and the cars were received, and that the defendant accepted two cars of seed. Under such circumstances, the fact that the seed in all the cars was of the same quality would have a material bearing on whether or not the defendant rejected the seed on the ground of quality."115 Another case mentions the drop in the market (and note that it was a 1920 sugar case) and that thereafter the buyer tried to cancel its contract, the court practically saying that it was because of the drop in the market that he cancelled, but nowhere making that belief explicit or in any wise stressing it. ${ }^{116}$ In the rest of the cases in this group, with only one exception, there is no evidence that the court knew of the market drop, but the breach in the majority occurred in fact on a depressed market. ${ }^{117}$ The single exception is a case in which

115. Phillips, J. in $10 \mathrm{~F}$. (2d) 467,471 (C. C. A. 8th, 1926) (defect remediable).

116. Second Nat. Bank of Allegheny v. Lash Corp., 299 Fed. 371 (C. C. A. 3d, 1924), cited note 21, supra.

117. Name of Case

Miller v. Ungerer, 188 App. Div. 655,176 N. Y. Supp. 850 (2d Dep't, 1919)

Smith v. Moscahlades, 193 App. Div. 126, 134, 184 N. Y. Supp. 500, 507 (1st Dep't, 1920)

Hyman v. Hu'Iman, 205 Apn. Div. 119, 124, 199 N. Y. Supp. 366, 369 (1st Dep't, 1923)

Savannah Chemical Co. v. Wr. R. Grace \& Co., 293 Fed. 145 (C. C. A. 5th, 1923)

O'Meara v. National Park Bank, 239 N. Y. 386, 146 N. E. $630^{\circ}$ (1925)

Business Conditions at
Time of Breach.
Manner of Price Fluctua-
tion of Specific Commodity
Between Dates of Contract
and Breach.
Partly Cloudy (1915)
Fair (1916)
Steady (codfish)

Partly Cloudy-Stormy
(1920-1)
Decline (nitrate of soda)
Partly Cloudy-Stormy
(1920-1)

\section{Business Conditions at Time of Decision. \\ Source of Information.}

Fair

Partly Cloudy

U. S. Burcau Labor Stat. Wh'sale Commod. Pr. Bull. 266, p. 80.

Fair

Fair

U. S. Bur. Labor Stat. Bull. 320, p. 216.

Fair

There are two cases, Hill v. Fruita Mercantile Co., 42 Colo. 491, 94 Pac. 354 (1908) and Trevas \& Schack, Inc. v. Napel Mills Co., 241 Mass. 452, 135 N. E. 477 (1922), that could not be forced into any of the classes without doing too great violence to the cascs. They do not, however, disturb the above conclusions. Their analysis is:

Hill v. Fruita Mercantile Co.

Squall (1903)

Clearing

Trevas \& Schack v. Napel

Fair (1919)

Stormy Mills Co. 
price disputes indicate that there was a dropping market as to the specific commodity. 118

A canvassing of the foregoing data will reveal that of the entire list of cases decided in favor of the seller after Ginz v. Clask, the factor of depression is present in two-thirds. ${ }^{119}$ It thus appears that there is in fact no genuine precedent-tradition growing out of the Littlejoltn and Ginn cases.

Another check on the data presented will show that in the full sweep from before Littlejoin v. Shaw up to the present, two-thirds of all the cases reveal a generally depressed market or a price drop in the specific commodity. ${ }^{120}$ Considering this, it is believed justifiable to say that this line of decisions, taken as a whole, may not be reasonably regarded as precedent for the proposition that unstated defenses may not be relied upon at trial even when neither price drop nor any other element is present which might justify their preclusion. In dealing with Sales cases of this type, therefore, the courts should pay no heed to seeming precedent barring unstated defects, unless an examination of the fact situation in each particular case reveals either that the seller actually and reasonably suffered material damage as a result of the buyer's failure to include all his defenses in his first statement of defect, or else that the buyer is actually endeavoring to escape from a contract which adverse market conditions has rendered burdensome to him.

\section{RECOMDIENDATIONS}

After tracing the vagaries of the rule precluding unstated defects from being set up as defenses, a statute designed to incorporate into the law what business men would concede was a fair treatment of their dealings can now be proposed. Such a statute should put the burden on the seller of demanding a formal statement of defects. But such statement by the buyer should neither bar defects of which the buyer could not have knowledge, nor should it bar use of unstated defects about which the seller ought reasonably to have known. As to all other defects, whether remediable or not, the formal statement, once requested, should act as a conclusive bar. Only so can compromise-adjustment be encouraged. If the buyer, acting as a normal business man unaware of his legal rights, sends a notice before demand by the seller for a particularized statement, such notice should not act as a bar unless it has

118. Hyman v. Hullman, 205 App. Div. 119, 199 N. Y. Supp. 366 (1st Dep't, 1923), cited note 8 , supra (rejection because price too high and no opportunity to examine).

119. The numerical count comes to 32 cases containing the factor of depression, 25 against 15 not containing that factor.

120. A numerical count similar to note 119 , supra comes to 44 cases with the depresion factor present as against 21 without that factor. 
misled the seller into doing or refraining from doing some available act to protect his interest. Such a reliance on the statement by the seller must occur in fact (there must be no presumption that the necessary effect of the statement is to mislead); the seller's reliance must be reasonable, tested by the standards of the ordinary business man; and he must have suffered some damage thereby. Also, such statement should act as a bar if the circumstances in which it is sent, together with the reasons assigned, indicate that the defects left unstated were not really material to the buyer. Finally, the buyer must not be protected if he says or does nothing after receipt of the seller's demand. He must be placed under a duty to reply; and failure to perform that duty within a reasonable time should result in a barring of all defects which have not been communicated to the seller prior to the receipt of the demand.

Such a statute, which could be considered an addition to Section 49 of the Uniform Sales Act, would read:

\section{Section 49.}

(2) (a) The buyer is barred from setting up unstated defects in any subsequent litigation, when he gives notice of objections before demand therefor, only if his notice actually, reasonably, and materially misleads the seller or if his statement, together with the surrounding circumstances, indicates that the unstated defects were not really material to his rejection. The burden of proving actual, reasonable, and material reliance and immateriality of the unstated defect is on the seller.

(b) The seller is entitled, on demand therefor, to a formal statement of all objections readily ascertainable by the buyer at the time of such demand. Such statement will bar the setting up in any subsequent litigation of any defect unmentioned whose existence was not already reasonably ascertainable by the seller. Failure to reply to the seller's demand with a formal statement of objections within a reasonable time will bar the setting up in any subsequent litigation of all objections not specified prior to the receipt of such demand. 